\title{
Lithostratigraphic development and neotectonic significance of the Quaternary sediments along the Kachchh Mainland Fault (KMF) zone, western India
}

\author{
V Chowksey, D M Maurya, Parul Joshi, N Khonde, Archana das and L S Chamyal* \\ Department of Geology, The M. S. University of Baroda, Vadodara 390 002, India. \\ ${ }^{*}$ Corresponding author.e-mail: lschamyal@yahoo.com
}

\begin{abstract}
The Kachchh Mainland Fault (KMF) is a major E-W trending seismically active fault of the Kachchh palaeorift basin whose neotectonic evolution is not known. The present study deals with the eastern part of the KMF zone where the fault is morphologically expressed as steep north facing scarps and is divisible into five morphotectonic segments. The Quaternary sediments occurring in a narrow zone between the E-W trending KMF scarps and the flat Banni plain to the north are documented. The sediments show considerable heterogeneity vertically as well as laterally along the KMF zone. (The Quaternary sediments for a northward sloping and are exposed along the north flowing streams which also show rapid decrease in the depth of incision in the same direction.) The deposits, in general, comprise coarse as well as finer gravelly deposits, sands and aeolian and fluvial miliolites. The Quaternary sediments of the KMF zone show three major aggradation phases. The oldest phase includes the colluvio-fluvial sediments occurring below the miliolites. These deposits are strikingly coarse grained and show poor sorting and large angular clasts of Mesozoic rocks. The sedimentary characteristics indicate deposition, dominantly by debris flows and sediment gravity flows, as small coalescing alluvial fans in front of the scarps. These deposits suggest pre-miliolite neotectonic activity along the KMF. The second aggradation phase comprises aeolian miliolites and fluvially reworked miliolites that have been previously dated from middle to late Pleistocene. The youngest phase is the post-miliolite phase that includes all deposits younger than miliolite. These are represented by comparatively finer sandy gravels, gravelly sands and sand. The sediment characteristics suggest deposition in shallow braided stream channels under reduced level of neotectonic activity along the KMF during post-miliolite time evidenced by vertical dips of miliolites and tilting of gravels near the scarps. The tectonically controlled incision and dissection of the Quaternary deposits is the result of neotectonic activity that continues at present day. The overall nature, sedimentary characteristics and geomorphic setting of the sediments suggest that the KMF remained neotectonically active throughout the Quaternary period.
\end{abstract}

\section{Introduction}

The Kachchh basin is a seismically active palaeorift graben located on the western continental margin of India (Biswas and Khattri 2002). The basin is traversed by several large $\mathrm{E}-\mathrm{W}$ trending faults that bound uplifts on their upthrown side, viz., the Mainland uplift, the Wagad uplift, the Desalpar uplift and the Island belt uplift (figure 1). The various faults bounding these uplifts are the Kachchh Mainland Fault (KMF), The South Wagad Fault (SWF), the Gedi Fault and the Island Belt Fault

Keywords. Stratigraphy; colluvium; fluvial deposits; neotectonics; Kachchh Mainland Fault (KMF).

J. Earth Syst. Sci. 120, No. 6, December 2011, pp. 979-999

(C) Indian Academy of Sciences 


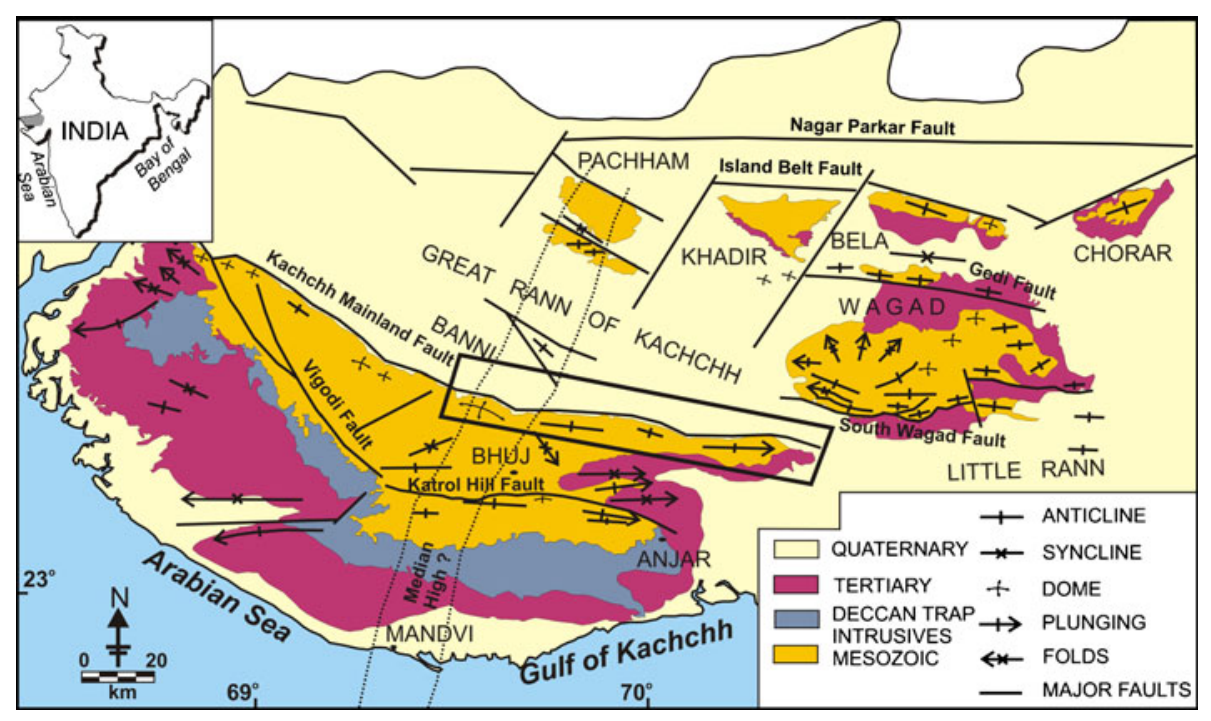

Figure 1. Tectonic map of Kachchh basin (after Biswas 1993). Boxed area shows the area of present study (inset - location map).

(IBF), respectively. The uplifts expose Mesozoic rocks deposited in the rift phase of the basin until late Cretaceous with a pronounced flexure zone comprising domes and anticlines of various shapes and sizes that form $\mathrm{E}-\mathrm{W}$ trending hill ranges along the faults (Biswas 1987). The post-rift inversion phase of the Kachchh since late Cretaceous is characterized by uplifting movements along the various faults leading to the evolution of the present tectonically controlled landscape configuration of the basin (Biswas 1974; Biswas and Khattri 2002).

The KMF is a major fault that bounds the Mainland uplift in the north beyond which lies the flat expanse of the Banni-Great Rann basin. The fault trends WNW-ESE in the western part while it trends $\mathrm{E}-\mathrm{W}$ in the eastern part. The fault is known to have suffered several phases of tectonic activity during the Cenozoic (Biswas 1974, 1987, 1993) and has been found responsible for the several earthquakes in historic times including the 2001 Bhuj earthquake, 1956 Anjar earthquake and the 1819 Allahbund earthquake as well (Chung and Gao 1995; Bilham 1998; Biswas and Khattri 2002). However, Quaternary tectonic evolution of the KMF is not yet precisely understood. Investigations of Quaternary deposits in fault zones are crucial for delineating neotectonic evolution of faults as demonstrated in the case of Katrol Hill Fault in the central part of Mainland Kachchh (Patidar et al 2007, 2008). In this article, we document the Quaternary sediments occurring in the eastern part of the KMF zone (figure 1) for understanding its Quaternary evolutionary history. We also provide a lithostratigraphic framework of the Quaternary sediments and discuss the neotectonic implications.

\section{Geomorphic set-up and morphotectonic segments}

The general geomorphic set-up of the KMF zone in the study area comprises the rugged topography of the E-W trending Northern Hill Range in the south, a 1-3 km wide zone of northward sloping Quaternary sediment cover and the flat Banni plain further north (figure 2a and b). The hill range displays a rugged mountainous topography developed in the Mesozoic rocks which form discrete domes of various sizes (figure 2a). The E-W trending Northern Hill Range comprises various domal structures like Jhura Hill, Habo Hill, Wantra dome, Devisar dome and other small domes (Biswas 1987, 1993). The domes expose rocks belonging to the Jhurio, Jumara, Jhuran and Bhuj formations that range in age from middle Jurassic to late Cretaceous (Biswas 1987). The formations comprise diverse sedimentary rocks like sandstones, shales and limestones. The northern limb of the domes is steeper as a consequence of the tectonic movements along the KMF that truncates the northern margin of the hill range, while the southern limbs show gentle dips. The Jhura dome is the largest followed by the Habo dome in terms of the area covered. The domal hills are separated by inter-domal depressions through which major drainages flow. To the east of Devisar, the hill range appears to go down below the Samakhyali-Lakadiya plain.

The steep north facing scarps demarcating the northern limit of the Northern Hill Range marks the geomorphic expression of the KMF. The imposing north facing scarp comprises steep north dipping Mesozoic rocks having a trend E-W to ESE-WNW 

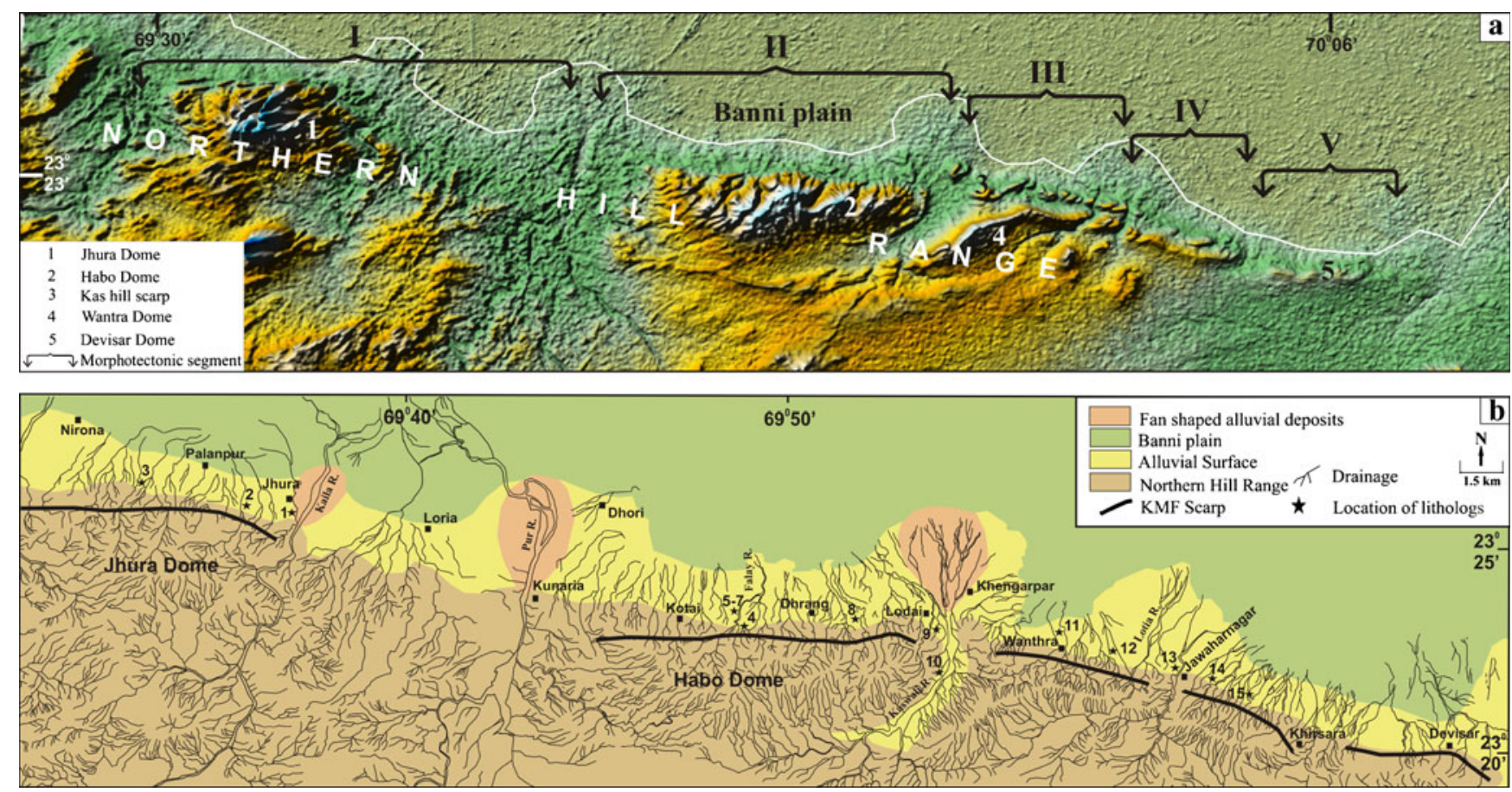

Figure 2. (a) DEM of the eastern part of the KMF showing the general morphology and morphotectonic segments. Note the north facing scarps and the narrow zone of Quaternary alluvial deposits between the scarps and the Banni plain. (b) Geomorphic map of the study area. Note the radial drainage pattern especially over the large Jhura and Habo domes and the north flowing drainages traversing the KMF zone and dying out in the Banni plain. Location of lithologs in figures 3-6 are also shown.

marks a prominent geomorphic expression of the KMF (figure 2a). Overall, the KMF zone displays the characteristics of a dynamic range front environment that is evident from the steep fault scarp, incised valleys, entrenched meanders, northward sloping alluvial surfaces and predominantly coarse grained colluvio-fluvial deposits. The domal hills are characterized by typical radial drainage patterns (figure 2b). Major rivers of the area flow in the inter-domal depressions, which are fed by streams arising from the gentle southern limbs of the domes. The drainage to the north of the scarps is dominated by the north flowing parallel rivers that incise through the Quaternary sediment cover and disappear in the Banni plain further north (figure 2a). The KMF zone is traversed by several north flowing streams originating in the hilly terrain of the Northern Hill Range (figure 2b). The north flowing rivers arising in the domal hills, form narrow, deep valleys and gorges within the Mesozoic rocks and follows incised channels to the north of the scarp line. The incision is found to rapidly decrease towards north as the streams die out as they reach the Banni plain.

The KMF is not a continuous fault, but is laterally displaced by several NNE-SSW to NNWSSE trending transverse faults (Biswas 1993). These faults have also been periodically reactivated along with the KMF during the post-rift tectonic evolution of the Mainland Kachchh (Biswas 1993; Maurya et al 2003a). These transverse faults are traceable within the Mesozoic rocks and are evidenced by offset fault scarps of the KMF, beheaded/deflected or offset drainage, sags, shutter ridges and pressure ridges (Maurya et al 2003a). A significant feature observed is that all major transverse faults displacing the KMF and truncating the domes are occupied by a high-order river channel debouching into the Banni plain (Maurya et al 2003a). For example, the Nirona, Kaila, the Pur and the Kaswali rivers in the study area flow along the inter-domal transverse fault zones. Based on the tectonic framework that includes the existence of several transverse faults (Biswas 1993; Maurya et al 2003a) and the corresponding geomorphic set-up, we divide the KMF zone in the study area into five morphotectonic segments from west to east (figure 2a). The segment-I is located between Nirona and Pur rivers, segmentII is between Kunaria and Lodai, segment-III is between Lodai and Jawaharnagar, segment-IV is between Jawaharnagar and Khirsara, and segment$\mathrm{V}$ is between Khisara and Devisar and beyond. The morphotectonic segmentation of the KMF was found necessary to compare the stratigraphic development of the Quaternary sediments in relation to neotectonic activity along various parts of the KMF zone in the study area. 


\section{Quaternary sediments of the KMF zone}

The exposed Quaternary sediments in all the morphotectonic segments of the KMF zone in the study area were investigated. Vertical lithologs were prepared and lateral variations in sedimentary facies were also documented. The occurrence of Quaternary deposits along a 1-3 km wide zone between the KMF scarps and Banni plain is extremely significant (figure $2 \mathrm{~b}$ ). These deposits average 5-10 m in thickness and display wide variation in lithology, both in the northward direction and laterally along the KMF zone. The deposits, in general, comprise coarse as well as finer gravelly deposits, sands and aeolian and fluvial miliolites. These deposits effectively conceal the KMF fault line below them and form a north sloping surface that merges with the Banni plain. The northward sloping surface developed over the Quaternary deposits is consistent with the decreasing depth of incision in this direction. The Nirona, Kaila, Pur and the Kaswali rivers have given rise to fan-shaped alluvial deposits at their mouths near the KMF zone (figure $2 \mathrm{~b}$ ). These are formed due to dispersal of recent sandy alluvium as the river loses gradient and bifurcate into small indistinct channels before disappearing in the Banni plain. The fan-shaped alluvial deposits, therefore, form the stratigraphically youngest Quaternary deposits of the KMF zone. The Quaternary deposits exposed in the cliff sections of the various north flowing streams have great significance for understanding the neotectonic evolution of the KMF. We describe the Quaternary sediments exposed in various morphotectonic segments separately.

\subsection{Segment-I}

This segment lies to the north of Jura dome and extends from Nirona in the west to Pur river in the east (figure 2a). The segment is characterized by a northward sloping surface developed over the Quaternary deposits. The surface abuts against the KMF scarp in the south and gently grades into the flat terrain of the Banni plain in the north. In general, the maximum thickness is exposed closer to the scarps corresponding to the incision pattern which shows a northward decreasing pattern mentioned earlier. Lithologs of the sections studied in this segment are shown in figure 3 .

The maximum thickness of the sediments is exposed along the Kaila river that flows along the eastern most fringe of the Jhura dome. The Quaternary sediments are exposed in continuous line of vertical cliffs on left bank from Sodha camp to Jhura village in the north (figure $2 b$ ). South of Sodha camp, the cliff exposing Mesozoic rocks of same height are observed. The Quaternary sediments rest unconformably over the northeast dipping Mesozoic sandstones which are also incised (figure 3 , litholog 1 ). In the upstream reach, the bottommost $2-3 \mathrm{~m}$ part of the cliff section comprises Mesozoic rocks. The overlying $\sim 12 \mathrm{~m}$ thick Quaternary sediments is divisible in distinct lithologic units. All units are separated by erosional contacts. The succession starts with a $4 \mathrm{~m}$ thick clast supported massive bouldery gravel overlying the Mesosoic rocks (figure 4a). The average size of the boulder is $\sim 50 \mathrm{~cm}$, whereas the largest boulder is approximately $0.6 \mathrm{~m}$ (figure $4 \mathrm{~b}$ ). The large boulders are enclosed in a matrix of cobble-to-pebble sized fragments. A small amount of interstitial sand appears to have been introduced subsequently. The lithoclasts are dominantly consisting of Mesozoic sandstones. The clasts are highly angular and subrounded. The bigger boulders are concentrated in the basal part of the unit. The vertical change in the clast size is because of the change in shear stress over the bedform. Higher sediment concentration, cohesive matrix and little internal sorting are the indicative of hyperconcentrated pseudoplastic debris flow (Miall 1996). The higher content of bigger clast size, texture, absence of sedimentary structures indicate cohesionless, non-viscous pseudoplastic debris flow with internal bedload that deposited poorly graded massive gravel (e.g., Blair and Mcpherson 1992; Aziz et al 2003; Garzione et al 2003; Dorsey and Roering 2006; Pope et al 2008).

The basal boulder gravel unit is overlain by $5 \mathrm{~m}$ thick gravelly sand. This unit dominantly comprises several gravel rich layers separated by relatively thinner sandy horizons. The gravel shows angular clasts of pebble size that are enclosed in a matrix of finer gravels and sand. The intervening sands are discontinuous and of lensoid nature. The angular nature of the clasts testifies to the short distance transport which is in conformity with the geomorphic setting of the deposits. The absence of sedimentary structure and occurrence of unorganized pebbles in coarse sandy matrix suggest rapid deposition by sediment gravity flows or debris flows (Rust 1978; Miall 1996; Stokes and Mather 2000; Aziz et al 2003). The gravelly sand is overlain by $2 \mathrm{~m}$ thick matrix supported cobbly pebbly gravel. The individual clasts are found to be $20-40 \mathrm{~cm}$ size. The matrix is composed of rock fragments of smaller size. The clasts and matrix are angular in nature. The unit shows a considerable thickness along the cliff section and a general decrease in clast size towards north. The presence of matrix suggest the cohesive, viscous nature of depositing flow whereas, the absence of sedimentary structure and the fabric indicate the sediment deposition by debris flows (Rust 1978; Miall 1996). All these lithofacies characteristics indicate the deposition 


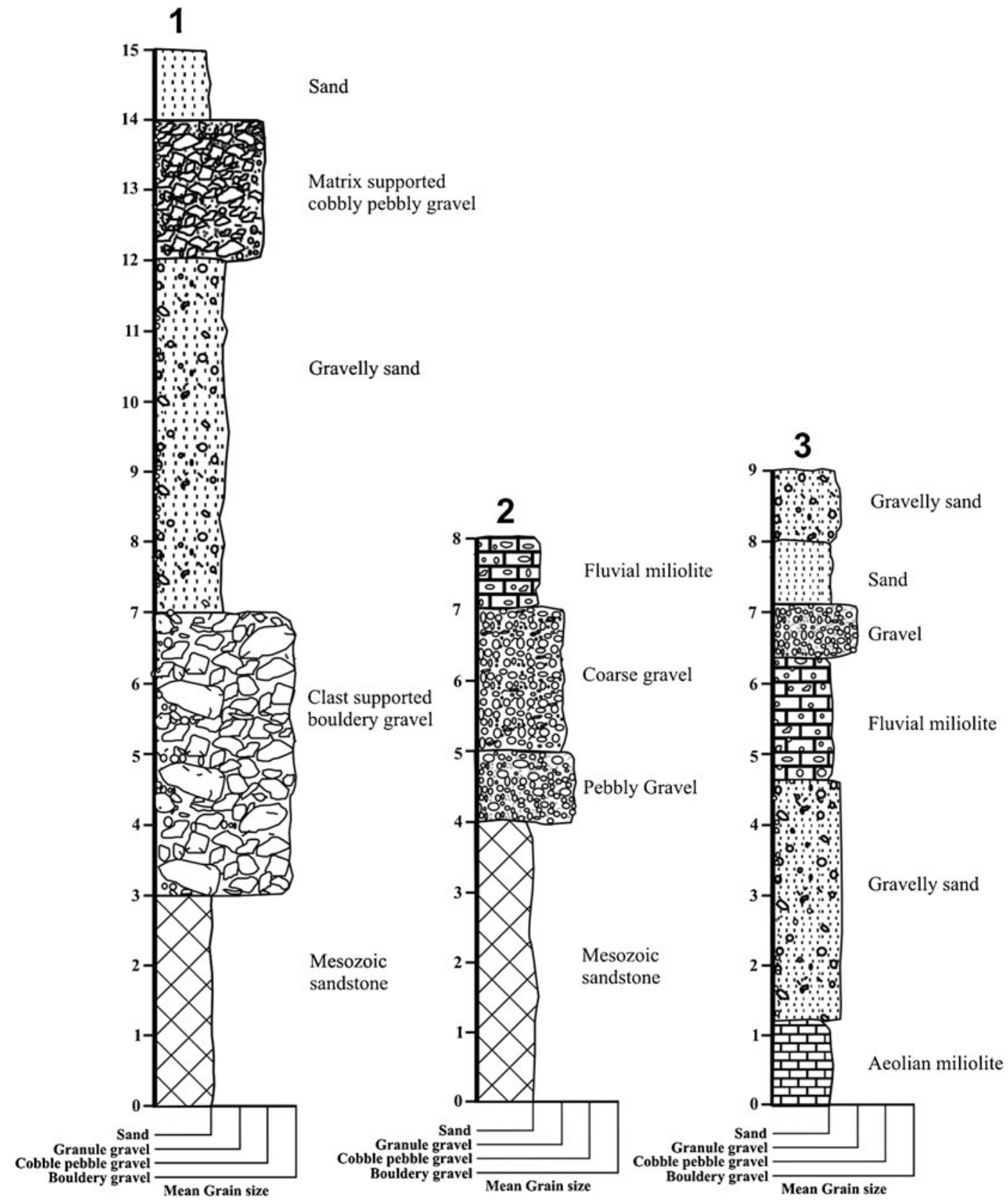

Figure 3. Lithologs of Quaternary sediments in segment-I. Location of the lithologs is shown in figure 2(b). The vertical scale is in metres.

by viscous, high strength clast rich debris flows (e.g., Blair and Mcpherson 1992; Garzione et al 2003; Dorsey and Roering 2006; Pope et al 2008). The top of the section is marked by $1 \mathrm{~m}$ thick structureless sand deposited by sediment gravity flows.

The main characteristic of these deposits is their occurrence in imposing cliffs on the left bank of the Kaila river and its dominance of highly angular coarse grained fluvial deposits. A general decrease of sediment size to the north, which is the downstream direction, is very obvious. The sediments exposed in the cliffs are in complete contrast to fine grained sandy bedload in the present day channel of the river. The section is reduced to $\sim 6 \mathrm{~m}$ to the east of Jhura village where the cliff section gradually goes below the recent fan-shaped sandy alluvium of the Kaila river further north.

To the west of Jhura, the Sonva nala stream also exposes Quaternary sediments along its 8$10 \mathrm{~m}$ high incised cliffy bank (figure 3, litholog 2). The river follows a $\mathrm{N}-\mathrm{S}$ oriented gorge like incised course for about $2 \mathrm{~km}$ after emerging from the hilly terrain of the eastern part of Jhura dome. The stratigraphic development is restricted compared to Kaila river. Here the Quaternary deposits overlie 

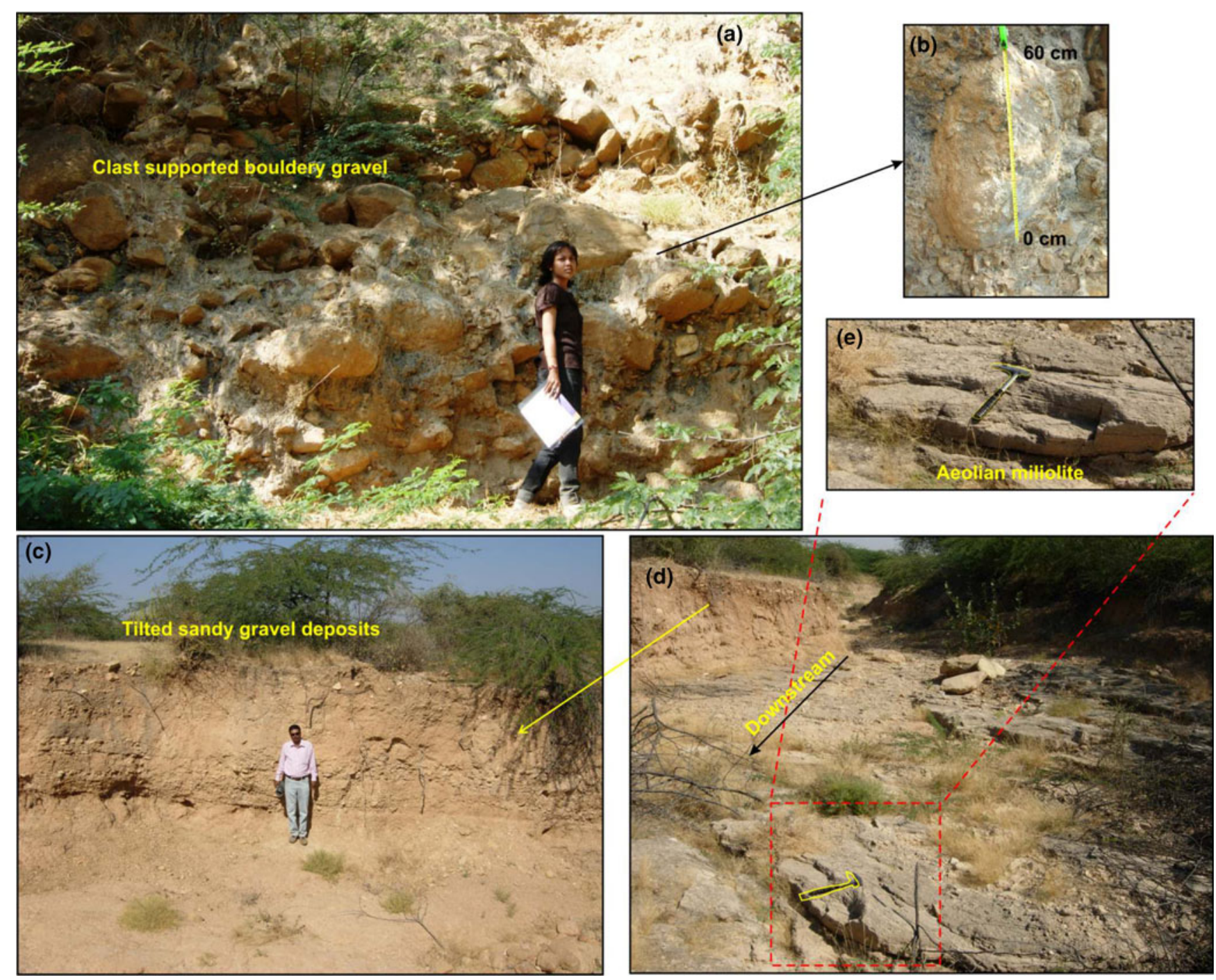

Figure 4. (a) Close view of clast supported bouldery gravel at the base of the exposed cliff section in Kaila river to the south of Jhura. (b) Close view of the largest boulder observed. The size of the clast is $0.6 \mathrm{~m}$. (c) Tilted sediment succession of Quaternary deposits exposed in a lower order stream in segment-I. (d) View of aeolian miliolite forming the floor of the incised valley shown in (c). Note the fine grained nature of the deposit and the aeolian cross bedding. (e) Close view showing the aeolian cross bedding in the mioliolite deposit shown in (d).

the north dipping Mesozoic sediments which form about $4 \mathrm{~m}$ of the basal part of the cliff section. The Mesozoic rocks are unconformably overlain by $\sim 1 \mathrm{~m}$ of pebbly gravel. The gravel is matrix supported and consists of clasts of Mesozoic sandstone. The unorganized, structureless pebbles and abundant coarse matrix indicates the cohesive nature of depositing agent. As the lithofacies comprises of matrix rich gravel with absence of sedimentary structures it can be inferred that the sediments were deposited by cohesive, low strength turbulent or laminar flow with an inertial bedload. Absence of imbrication, sorting and sedimentary structures suggest rapid deposition by cohesive clast rich sediment gravity flows (Rust 1978; Miall 1996; Blair and Mcpherson 1992; Garzione et al 2003; Dorsey and Roering 2006; Pope et al 2008). They are overlain by coarse gravel which shows cobble-sized clasts. The cobble gravel is $2 \mathrm{~m}$ thick and easily distinguishable from the lower pebbly gravel unit by its grain size. The unit consists of cobble size clasts embedded in matrix of medium to fine sand. The clasts comprise rock fragments of shales and laminated sandstone and are platy in nature with their flat bases giving the appearance of pseudostratification. The clasts show high angularity and are imbricated in the downstream direction. Although the lithofacies have been deposited by the same depositional process as the former one, the increased clast size indicates relatively increased strength of the flows. The top of the exposed section is marked by compacted valley fill miliolites. It consists of sand sized grains of miliolitic sand cemented by calcareous matrix. The 
valleyfill miliolites also contain clasts of Mesozoic rocks of varying sizes embedded within the compacted miliolite grains which points to fluvial deposition. The valley fill miliolites owe their origin to erosion of aeolian miliolites in the upstream area which were fluvially reworked, carrying the Mesozoic rock fragments along with them and redeposited. This horizon brackets the underlying deposits together with those exposed along the Kaila river as of pre-miliolite phase.

Further west of Sonva nala river, the Quaternary deposits continue to form a north sloping surface in front of KMF scarps up to Nirona river. The surface is extensively directed by several north flowing streams including the Badi river that arises from the core portion of the Jhura dome. Good exposures of the sediments are observed in an unnamed lower order stream to the west of it that exhibits an incised course exposing varied lithologies of the Quaternary sediments (figure 4c). Here the section starts with aeolian miliolite which forms the floor of the incised valley (figure $4 \mathrm{~d}$ ). The aeolian origin of the miliolite is evident by its laterally extensive and uniformly fine grained nature and well developed aeolian cross bedding (figure 4e). The deposits form a part of the extensive obstacle dune that was formed in front of the KMF scarps, of which, a small part is exposed in the valley floor while the rest of it is covered by the younger Quaternary deposits. The aeolian miliolite is part of the regionally extensive and prolonged phase of miliolite deposits witnessed all over the Kachchh basin from Middle to Late Pleistocene (Baskaran et al 1989). The aeolian miliolite is overlain by $3.2 \mathrm{~m}$ thick gravelly sand that contains dispersed angular clasts of Mesozoic rocks (figure 3, litholog 3 ). The massive texture of the sand with presence of isolated clast and the absence of sedimentary structures suggest the rapid deposition of gravelly sand (Miall 1996). It is interpreted that the structureless fine-to-coarse pebbly sand was deposited as a sheetflood sedimentation by sediment gravity flow (Miall 1996; Stokes and Mather 2000; Coltorti et al 2010). This is followed by $\sim 1.7 \mathrm{~m}$ thick semicompacted valley-fill miliolite that characteristically shows stratification and angular pebbles of Mesozoic rocks.

A $0.7 \mathrm{~m}$ thick gravel overlies the valley-fill miliolite. The clasts include cobbles as well as boulders of sandstones. The large angular clasts are clast supported while the smaller ones are matrix supported. The entire sediment succession horizon shows marked tilting towards the north (figure 4c). The clasts are weakly graded, poorly sorted, and does not show imbrications and sedimentary structures which are the characteristic properties of debris flow deposits (Miall 1996). Further, the clast supported cobbles and pebbles indicate hyper- concentrated, low strength, clast rich pseudoplastic nature of the depositng fluid (Rust 1978; Miall 1996). Hence, it is inferred that the sediments were deposited by low strength pseudoplastic debris flow (e.g., Blair and Mcpherson 1992; Aziz et al 2003; Pope et al 2008). The gravel is followed by $\sim 1.0 \mathrm{~m}$ thick sand which in turn, is overlain by a $1 \mathrm{~m}$ thick gravelly sand marking the top of the succession. These both lithofacies have sheet-like geometry, massive texture and the absence of sedimentary structures suggest the deposition by sediment gravity flow that could be related to the sheetflood sedimentation (Miall 1996; Coltorti et al 2010). On the basis of miliolite deposits at the base, the overlying sediments are clearly the result of post-miliolite depositional phase. The tilting of the sediments provides strong evidence for reactivation of KMF in post-miliolite time.

\subsection{Segment-II}

This segment extends from Kunaria in the west to Lodai in the east and corresponds to the KMF zone to the north of the Habo dome (figure $2 \mathrm{a}$ and $\mathrm{b}$ ). The Quaternary deposit occurs in a $2-3 \mathrm{~km}$ wide band to the north of the KMF scarp developed in the northern limb of the Habo dome (figures 2b, 5a). The major rivers are the Pur and Kaswali rivers that flow in the saddles to the west and east of the Habo dome respectively. Between them several unnamed streams arising from the hilly topography of the Habo dome flow northward incising through the Quaternary sediments before disappearing in the Banni plain (figure $2 \mathrm{~b}$ ). All rivers expose variable thickness of their deposits overlying the Mesozoic rocks. Maximum stratigraphic development of the deposits is seen in the Falay river (figure 6). Vertical cliff sections in the Falay river and a small tributary near Falay on its right bank reveal the heterogeneity of the dominantly coarse grained fluvial deposits (figure 6, litholog $4)$. The deposits unconformably overlie the vertically dipping Mesozoic strata (figure 5a). In the downstream side, several tens of meters wide zone of highly sheared Mesozoic rocks underlie the Quaternary deposits. The dominantly coarse nature of the Quaternary deposits is very striking (figure 5). Overlying the Mesozoic rocks is a clast supported bouldery gravel which shows a maximum thickness of $\sim 6 \mathrm{~m}$ (figure $5 \mathrm{~b}$ and $\mathrm{c}$ ). The thickness varies along the river as it overlies the uneven topography of the underlying Mesozoic rocks. The unit shows several phases of deposition of very coarse gravel as seperated by $0.3-0.5 \mathrm{~m}$ thick discontinuous lensoid sand bodies of variable thickness within the gravels. The bottommost sand body is massive in nature and shows extensive 

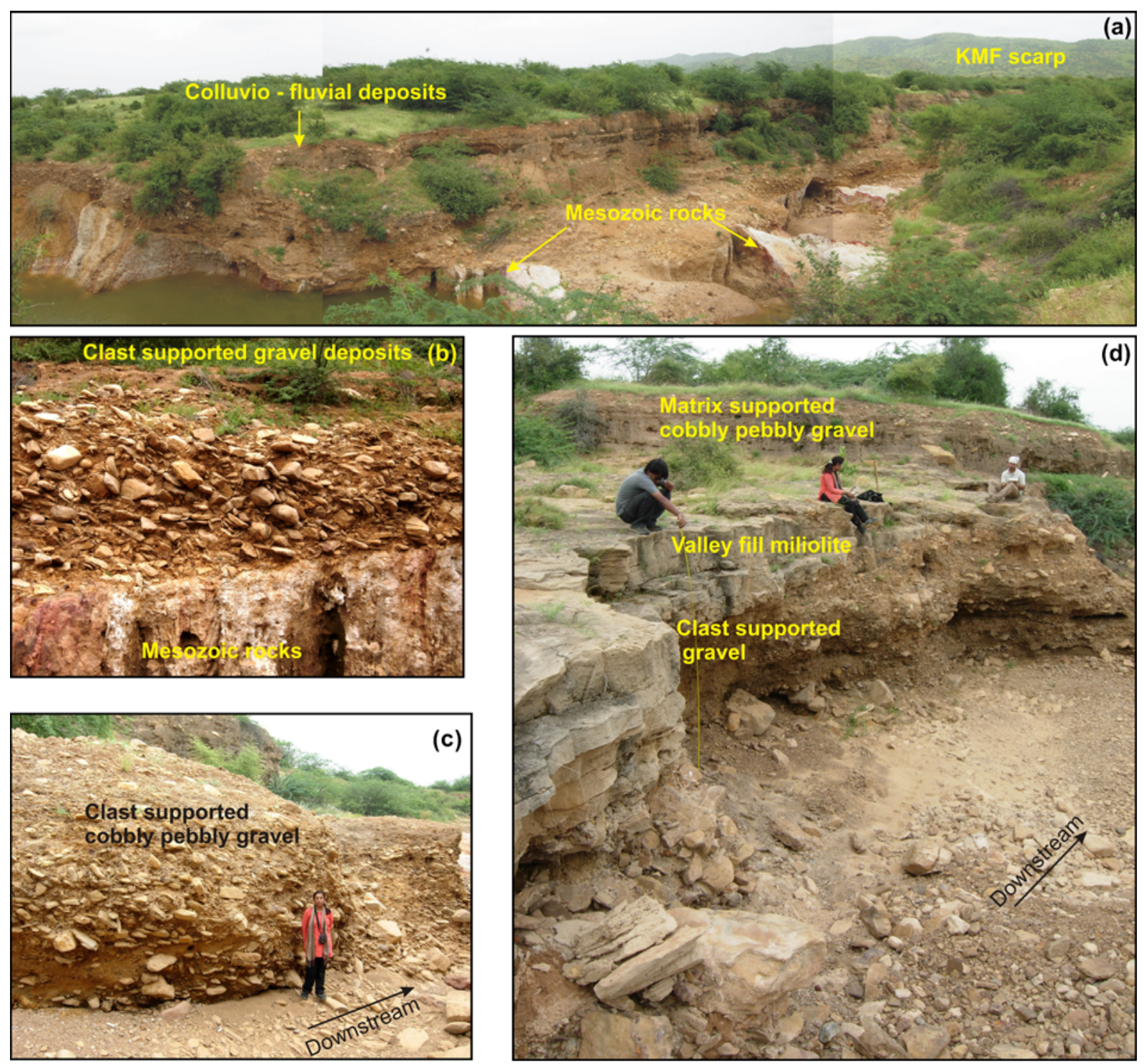

Figure 5. (a) Panoramic view of the KMF zone showing the field setting of the Quaternary colluvio-fluvial deposits along the Falay river. Note the flat surface formed over the colluvio-fluvial deposits exposed along the incised cliff of the river. Also seen are the vertical to subvertical sheared Mesozoic rocks in the riverbed and the sharp unconformable contact with the overlying stratified colluvio-fluvial deposits. (b) Close view of the colluvio-fluvial deposits resting uncomformably over the Mesozoic rocks in Falay river. (c) View of the clast supported gravel in Falay river. Note the coarse nature of the deposit and the angular nature of the clasts. (d) View of a knick point in Falay river showing the sedimentary succession. Note the valley-fill miliolite dividing the colluvio-fluvial deposits into two distinct phases. Location of the knick point is about half kilometer upstream of the photographs in (a), (b) and (c).

development of nodular calcretes. The clasts size is mostly cobbly but boulder size fragments also occur regularly. All clasts are highly angular and indicate very short transport. The general appearance is that of typically unsorted colluvium deposits, however fluvial reworking is indicated by distinct aggradation phases and intervening sandy layers. The extremely short transport is implicit from the geomorphic setting as the source area is less than a kilometer to the south in the hilly terrain of the Habo dome (figure 5a). We interpret these as debris-flow deposits as they are weakly graded, poorly sorted, and does not show imbrications and sedimentary structures. The occurrence of bigger clasts in large amount and massive texture indicate deposition by hyperconcentrated, low strength, clast rich pseudoplastic debris flows (Rust 1978; Blair and Mcpherson 1992; Miall 1996; Aziz et al 2003).

The thick colluvio-fluvial unit is overlain by 2-3 m thick valley-fill miliolites (figure $5 \mathrm{~d}$ ). The miliolite contains dispersed clasts of pebbles to large boulder size pointing to fluvial origin of the miliolite. The miliolite is again overlain by $2 \mathrm{~m}$ 


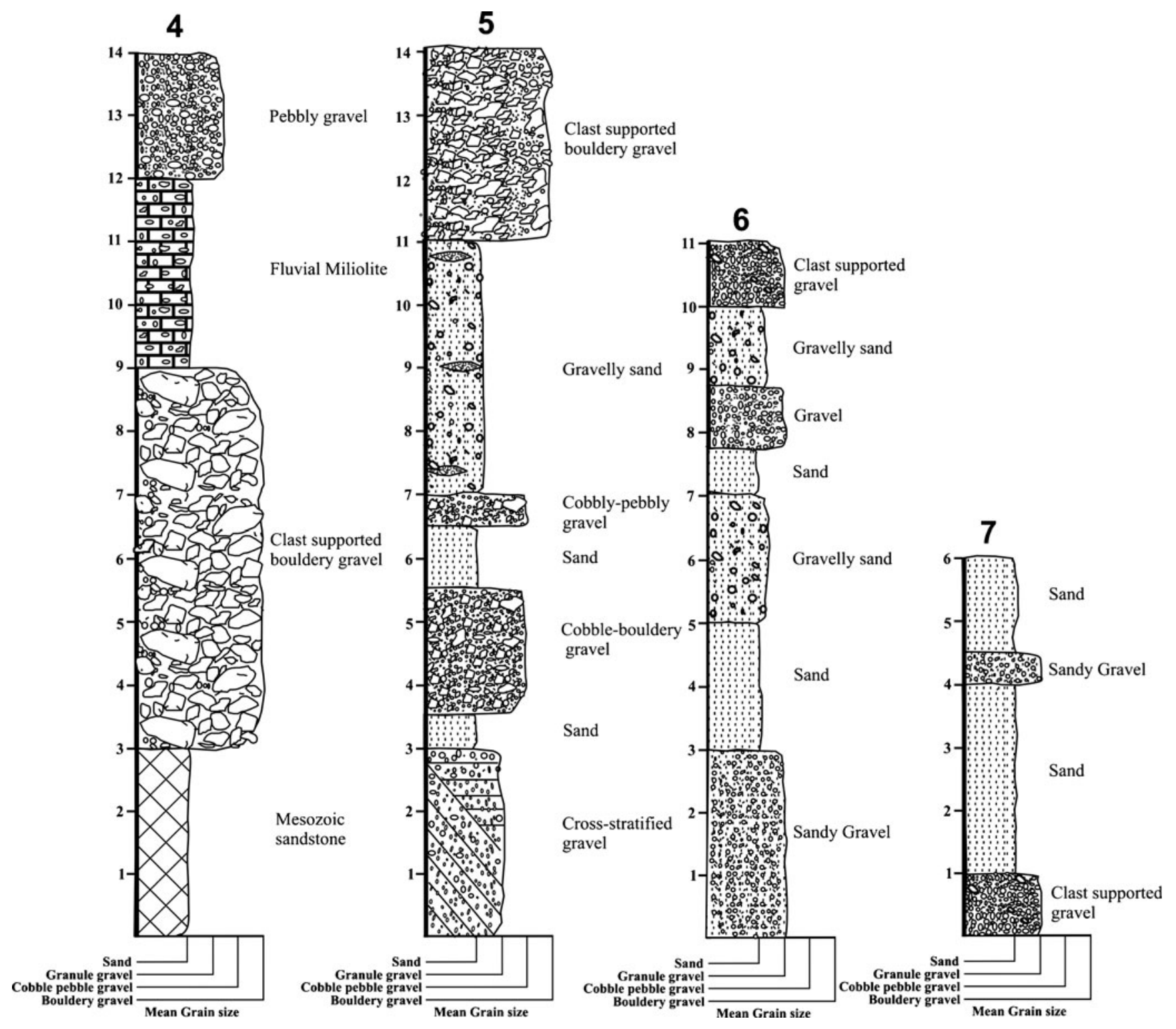

Figure 6. Lithologs of Quaternary sediments exposed in Falay river in segment-II. Location of the lithologs is shown in figure $2(\mathrm{~b})$. The vertical scale is in metres.

thick colluvio-fluvial deposit represented by matrix supported gravel (figure 5d). This unit shows finer clast size than the thick colluvio-fluvial deposits underlying the valley-fill miliolite. The presence of medium-to-coarse grained sandy matrix indicates the cohesive nature of depositing agent. The gravels are not imbricated, poorly sorted and do not display structures which suggest rapid deposition by sediment gravity flows (Rust 1978; Miall 1996). Overall, the presence of matrix and fabric suggest that the sediments are deposited by cohesive, clast rich debris flow (e.g., Blair and Mcpherson 1992; Garzione et al 2003; Dorsey and Roering 2006; Pope et al 2008).

About $1 \mathrm{~km}$ downstream, a $15 \mathrm{~m}$ thick section is exposed in a deeply entrenched meander (figure 6, litholog 5). The sediments are markedly finer than the above-mentioned section. At the base is a $3 \mathrm{~m}$ thick matrix supported gravel which shows large scale cross stratification. The clasts comprise pebble size rock fragment. The pebbles are supported by medium-to-coarse sand which indicate cohesive, viscous property of depositing medium whereas the presence of cross stratification indicates that the sediments could have been deposited as lag deposits (Miall 1996). It could be inferred that the sediments are lag deposits that were deposited by cohesive debris flow (Miall 1996; Garzione et al 2003; Dorsey and Roering 2006). Overlying this is a $0.5 \mathrm{~m}$ thick sand followed by $2 \mathrm{~m}$ thick cobbly gravel which shows sparsely distributed boulders as well. Above this is a $\pm 1 \mathrm{~m}$ thick sand followed by $0.5 \mathrm{~m}$ thick cobbly pebbly gravel. The sand facies is characterized by massive texture, lack of 
sedimentary structures and poor sorting which indicates depositon by sediment gravity flows (Miall 1996; Stokes and Mather 2000; Coltorti et al 2010). The overlying cobbly pebbly gravel lithofacies comprises subangular to subrounded, poorly sorted, coarse matrix supported gravels. The absence of sedimentary structures, poor grading and lack of sorting suggest the deposition by clast rich debris flows (Blair 1992; Miall 1996; Dorsey and Roering 2006; Kallmeier et al 2010). This is followed by $4 \mathrm{~m}$ thick horizontally stratified gravelly sand. The sand shows several gravel rich lensoid bodies. The gravels are of pebble size, subrounded and show horizontal stratification. On the basis of structure and sediment fabric we interpret that the lithofacies was deposited by clast rich laminated debris flow (Rust 1978; Miall 1996; Pope et al 2008; Coltorti et al 2010; Kallmeier et al 2010).

The top of the succession is marked by $3 \mathrm{~m}$ thick clast supported bouldery gravel. The poor sorting and grading, massive texture and the absence of sedimentary structures indicate deposition by viscous, hyperconcentrated clast rich debris flow (Rust 1978; Miall 1996; Aziz 2003; Pope et al 2008; Kallmeier et al 2010). The overall finer nature of the sediments is in conformity with the fact that the section is located downstream of the previously described section. Further downstream, a $11 \mathrm{~m}$ thick cliff section shows increasing content of sand and prominent decrease in clast size in the various gravelly layers (figure 6, litholog 6). However, the sediment succession is stratigraphically comparable. About a kilometer further downstream in the north, the cliff section is reduced to $6 \mathrm{~m}$. The section exposes $1 \mathrm{~m}$ thick clast supported gravel at the base followed by $3 \mathrm{~m}$ thick sand (figure 6 , litholog 7 ). This is overlain by $0.5 \mathrm{~m}$ sandy gravel and $1.5 \mathrm{~m}$ thick sand at the top.

Over all, the Quaternary sediments of the Falay river typifies the occurrence of these deposits in the KMF zone. The sedimentary characteristic reveals that the deposits are reworked colluvial deposits. The colluvium was generated in the hilly region comprising Mesozoic sedimentary formation in response to neotectonic uplift of the hill range along the KMF. These were later reworked by fluvial agencies and redeposited in front (to the north) of the range front scarps.

Another notable section exposing Quaternary deposits is found in an unnamed stream between Dhrang and Lodai. The section is $\sim 6 \mathrm{~m}$ in height, is exposed on the left bank close to the scarp

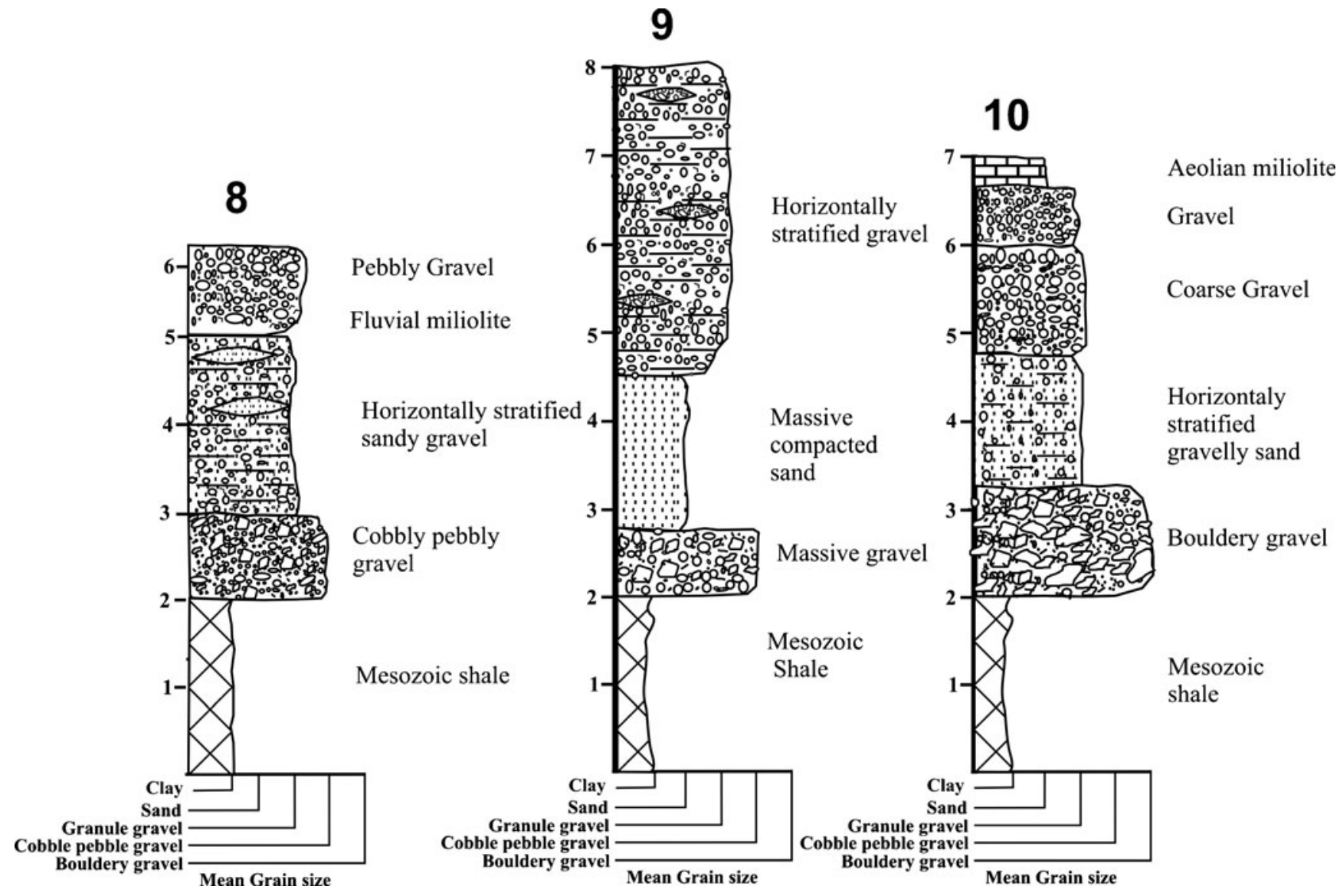

Figure 7. Lithologs of Quaternary sediments in segment-II. Location of the lithologs is shown in figure 2(b). The vertical scale is in metres. 
line (figure 7 , litholog 8 ). The lower $\sim 2 \mathrm{~m}$ of the incised section exposes steeply dipping Mesozoic shale over which the Quaternary sediments were deposited with a distinct unconformity. The Quaternary deposits are divisible into distinct aggradation phases, however, internal stratification is obscure. Overall, the section shows $\sim 5 \mathrm{~m}$ thick horizontal to sub-horizontal layers of gravelly to pebbly sediments with elongated lensoid bodies of sand. The bottommost matrix supported cobbly gravel unit is the coarsest with occasional clasts of boulder size. The matrix supported massive nature of cobbly-bouldary gravels indicate cohesive, viscous property of depositing medium whereas, the cross stratification structure suggests that it may have been deposited in the form of lag deposits (Miall 1996). It is inferred that the sediments are lag deposits that may have been deposited by debris flows (Blair and Mcpherson 1992; Miall 1996; Garzione et al 2003; Dorsey and Roering 2006; Pope et al 2008). This is followed by stratified sandy gravel which shows increased content of sand. The gravels are of pebble-to-cobble size, poorly sorted and graded, supported by sandy matrix suggest cohesive, viscous debris flow. It displays horizontal stratification indicating the deposition by laminated debris flow (Miall 1996; Pope et al 2008; Coltorti et al 2010; Kallmeier et al 2010). Towards the top, a distinct $0.5 \mathrm{~m}$ thick sandy body of massive nature is seen. The massive texture, lack of sedimentary structures and poor sorting indicate deposition by sediment gravity flows (Miall 1996; Stokes and Mather 2000; Coltorti et al 2010). The top of the succession is marked by pebbly gravel that shows several boulder sized clasts embedded in sandy matrix. The largest boulder measured is $\sim 0.60 \mathrm{~m}$. The presence of matrix indicates the cohesive nature of depositing agent, while absence of imbrication, poor sorting and sedimentary structures suggest the rapid deposition of sediments by sediment gravity flow (Rust 1978; Miall 1996). These sediments show a rapid fining of clasts within a short distance of less than a kilometre in the downstream direction. Near the Banni plain, the stream show fine sandy alluvium exposed along the vertical cliffs of $\sim 1 \mathrm{~m}$ height.

About $1 \mathrm{~km}$ south of Lodai, the sediments are exposed along a small stream that rises from the eastern flank of the Habo dome and meets the Kaswali river. The stream exposes $2 \mathrm{~m}$ of basement Mesozoic rocks (figure 7, litholog 9). The Quaternary section starts with a $0.7 \mathrm{~m}$ thick structureless clast supported bouldery gravel. The bigger angular clasts are encased in matrix of pebble size clasts. The facies exhibits bigger clasts in noticeable amount, massive clast supported structure, poorly sorted fabric, absence of stratification and imbrications and weak grading that suggests deposition by low strength hyperconcentrated clast rich debris flow (Rust 1978; Miall 1996; Aziz 2003; Pope et al 2008; Kallmeier et al 2010). This is overlain by $1.7 \mathrm{~m}$ thick massive sand with thin lenses of fine gravel. The massive texture, lack of sedimentary structures and poor sorting indicate depositon by sediment gravity flows (Miall 1996; Stokes and Mather 2000; Coltorti et al 2010). The top $3.5 \mathrm{~m}$ is composed of well stratified matrix supported gravel. The gravels are of pebble-to-cobble size and supported by fine-to-coarse sandy matrix, poorly sorted and weakly graded which indicate sediment gravity flow, whereas, the presence of horizontal stratification, indicates the deposition by high strength, clast rich laminated debris flow deposits (Miall 1996; Pope et al 2008; Coltorti et al 2010; Kallmeier et al 2010).

Further south of this section, about $1 \mathrm{~km}$ in the upstream direction of the Kaswali river, the Quaternary sediments are exposed in the long $\mathrm{N}-\mathrm{S}$ trending cliff section on the left bank of the river. The deposits form a distinct terraced surface that is incised by $>6 \mathrm{~m}$ (figure 7 , litholog 10). The vertical section shows $\sim 2 \mathrm{~m}$ of steeply dipping Mesozoic rocks that are part of the eastern flank of the Habo dome. Overlying it is a $1.5 \mathrm{~m}$ thick boulder bed with a sharply erosional basal contact. The horizon shows large highly angular boulder sized clasts which are crudely imbricated in the downstream direction. The matrix consists of finer clasts of Mesozoic rocks. The matrix supported texture indicates cohesive, viscous property of depositing medium whereas, the crude stratification indicates the sediments could be deposited in the form of large longitudinal bar deposited by debris flow (e.g., Miall 1996; Garzione et al 2003; Dorsey and Roering 2006). This is followed by a horizontally stratified sandy horizon containing sparsely distributed gravel clasts. The horizontal stratification, occurrence of floating gravels and poor sorting indicate transverse bedform sedimentation by laminar sediment gravity flows (Miall 1996; Stokes and Mather 2000; Coltorti et al 2010). The sand is overlain by a coarse gravel layer consisting of pebble-sized clasts. This is capped by a finer structureless gravel. The absence of sedimentary structures, weak grading, poor sorting and absence of imbrications suggest that gravels are deposited by low strength, hyperconcentrated clast rich debris flow (Rust 1978; Miall 1996; Aziz 2003; Pope et al 2008; Kallmeier et al 2010) whereas the decreased clast size of the overlying gravelly lithofacies may be attributed to change in hydraulic properties of the depositing flows (Miall 1996). The deposits are overlain by thin veneer of aeolian miliolite most part of which is eroded away. The exposed sediments are therefore bracketed as of pre-miliolite phase. 


\subsection{Segment-III}

This segment extends from the Lodai to the west and Jawaharnagar in the east. Here the scarps are developed in the Mesozoic rocks that form small domes forming a chain of small hills (figure 2a). South of these small hills is marked by the imposing presence of $\mathrm{E}-\mathrm{W}$ trending Kas hill escarpment. The Kas escarpment is prominently visible up to Jawaharnagar (figure 2a). The north facing Kas escarpment is a scarp face of a large cuesta that is formed in the south limb of the large Kas anticline. Biswas (1993) describes the domes between the KMF and the Kas escarpment as small domal closure within the large Kas anticline. Prominent domes amongst these are the Wantra and Lotia domes.

The Quaternary sediments in this segment are lithologically very distinct from those of previously described sediments in segment-I and segment-II. East of Lodai to Wantra, the sediments form a continuous alluvial cover. At Wantra, a stream coming out of the Wantra dome exposes $\sim 9 \mathrm{~m}$ of the Quaternary alluvial sediments on its right bank (figure 8, litholog 11). The base is marked by $1.5 \mathrm{~m}$ stratified sand. Overlying this is a $1 \mathrm{~m}$ thick semicompacted gravel. The overlying is $1.0 \mathrm{~m}$ sand. Sand is further followed by $3.5 \mathrm{~m}$ thick sandy gravel which shows several thin gravel rich layers. The gravel clasts are angular and unsorted. A $0.5 \mathrm{~m}$ structureless gravel overlies this. The top of the section is marked by $1.0 \mathrm{~m}$ thick sandy gravel. The overall sediment nature is finer as compared to the dominantly coarse grained sediments in segment-I and II to the west. Further upstream, aeolian miliolites abutting against the scarps are found to occur along the river, though they do not form vertical cliffs and are covered by dense vegetation. The aeolian miliolite outcrops become more extensive eastward along the scarps and occur discontinuously for few $\mathrm{km}$ directly overlying the Mesozoic rocks. The geomorphological setting suggests that the deposition of miliolite took place as obstacle dunes against the scarps Mesozoic rocks. The alluvial sediments described above therefore belong to post-miliolite phase of fluvial deposition. Further east of Wantra, a tongue of flat Banni plain is found to extend up to the scarps.

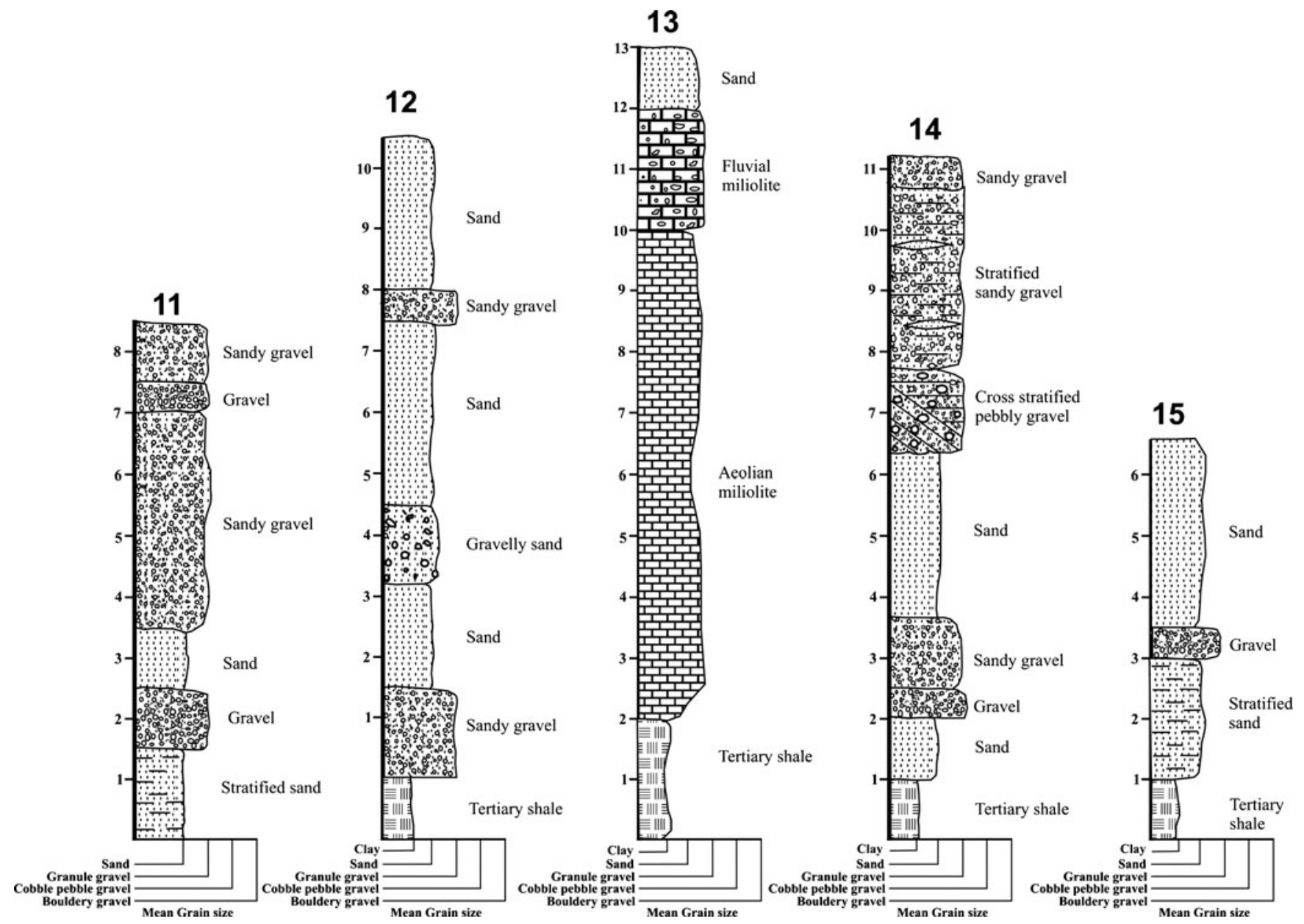

Figure 8. Lithologs of Quaternary sediments in segments III and IV. Lithologs 11-13 are from segment-III while lithologs 14-15 are from segment-IV. The vertical scale is in metres. 
The Lotia stream branches into two channels as it emerges from the hills. The western branch exposes continuous cliff section of Quaternary sediments overlying the Mesozoic rocks. It flows towards WNW and further towards NNW in the downstream before disappearing in the Banni plain (figure 2b). Mesozoic strata exposed in the river channel shows vertical dips. In the downstream, the basement rocks are replaced by near horizontal Tertiary shales. The river exposes mainly fine sandy alluvium with gravel layer overlying the sheared Mesozoic and Tertiary rocks (figure 8, litholog 12). Overlying the basement rocks is a $1.5 \mathrm{~m}$ thick gravel with an erosional contact. This is overlain by $1.7 \mathrm{~m}$ fine-to-medium sand that passes upward into gravelly sand which is $1.3 \mathrm{~m}$ thick. A prominent $3 \mathrm{~m}$ thick sand horizon with indistinct stratification follows. Overlying this thick sand is $0.5 \mathrm{~m}$ sandy gravel that is capped by $2.5 \mathrm{~m}$ sand marking the top of the section. Though the gravels are relatively less, lithologically they appear to be similar to the gravel horizons in the Wantra section. The deposits represent post-miliolite phase of alluviation as revealed by extensive miliolite deposits overlying the Mesozoic rocks to the east of Wantra and near Jawaharnagar in the west.

To the west of Jawaharnagar, a north flowing stream, bifurcates into two channels which flow further northward as independent streams to meet the Banni plain (figure 2b). The western channel follows a deeply incised channel exposing Quaternary sediments. The channel shows two major knick points within a distance of $1 \mathrm{~km}$ that show a vertical drop of $6 \mathrm{~m}$ and $5 \mathrm{~m}$, respectively away from the scarp. The Quaternary deposits exposed along the cliffy banks of the stream consists of $8 \mathrm{~m}$ thick aeolian miliolite, followed by $\sim 2 \mathrm{~m}$ thick valley fill miliolite capped by discontinuous $\sim 1 \mathrm{~m}$ thick fine alluvial sand (figure 8, litholog 13). The aeolian miliolite appears to have been deposited as a large obstacle dune in front of the scarp line as evidenced by an extensive mound like morphology of the deposits. The western fringe of the dune is buried by alluvial deposits exposed in Lotia stream. The WNW orientation of the Lotia stream is possibly controlled by neotectonic uplift of the miliolites with dunal morphology. The eastern margin of the presumed obstacle dune is buried under thick alluvial deposits to the east of Jawaharnagar described later. Near the scarp line on to the left bank of the stream the miliolite strata in contact with the Mesozoic rock shows vertical dips. The youthful topography, several knick points and vertically inclined miliolites near the scarps indicate post-miliolite reactivation of the KMF.

The significance of the Quaternary sediments in segment-III is that they are comparatively finer and contain a higher amount of sand than that of segment-I and II. The sedimentary succession comprises multi-storeyed bodies of gravel and sand. The constituent lithofacies are sandy gravel, sand and gravelly sand lithofacies. Thick sandy gravel facies comprises of well organized pebble clasts and fine-to-coarse grained sandy matrix. The lithofacies show moderate sorting and good lateral continuity. The alternating sand and gravelly sand lithofacies is composed of moderate-to-poorly sorted, massive and weakly stratified sand and gravel. The matrix varies from fine-to-coarse grained sand wherein floating pebbles are embedded.

Because, the gravelly facies are well stratified and include clasts which moderately imbricated, these can be interpreted as longitudinal bar deposits that filled up relatively shallow braided gravelly channels (Hein and Walker 1977; Garzione et al 2003). The sand may have been deposited on the top or flanks of bar during waning flow. In contrast to the alluvial fan lithofacies of segments I and II, these facies are finer and show better sorting as well as increased sand content. Furthermore, facies bases tend to be sharp and exhibits sheet geometry. Overall the sediments represent deposits of infrequent sheet floods in shallow braided stream channels (Rust 1978; Hein and Walker 1977; Miall 1977; Miall 1996; Garzione et al 2003; Kallmeier et al 2010).

\subsection{Segment- $I V$}

This segment lies between Jawaharnagar in the west to Khirsara in the east (figure 2a). The Quaternary sediment cover comprises mostly fine sandy alluvium that shows greatest thickness in the central part of the segment. The best exposure of Quaternary sediments is observed along a large entrenched meander of a stream flowing in the central part of the segment (figure 9a). The deeply incised meander is developed in alluvial sediments. The incision is however found to decrease rapidly to less than a metre near the Banni plain (figure 9b). The exposed sediments show a total thickness of $\sim 11 \mathrm{~m}$ (figure 8 , litholog 14). The sequence starts with a $1.0 \mathrm{~m}$ thick semi-compacted massive sand. The compact nature of sand is presumably because of the calcareous content derived from the older miliolite deposits well exposed near Jawaharnagar. This sand is overlain by $0.5 \mathrm{~m}$ thick semi-compacted clast supported lensoidal body of gravel. The gravel is followed by $\sim 1 \mathrm{~m}$ thick sandy gravel which is overlain by $2.6 \mathrm{~m}$ massive and unconsolidated fine-to-medium fluvial sand. Overlying this is a $1.2 \mathrm{~m}$ crudely cross stratified pebble gravel with sandy matrix and a scoured base. This is again overlain by $4.5 \mathrm{~m}$ thick well stratified and unconsolidated sandy gravel with lenses of sand. The top is marked by $0.5 \mathrm{~m}$ thick sandy 

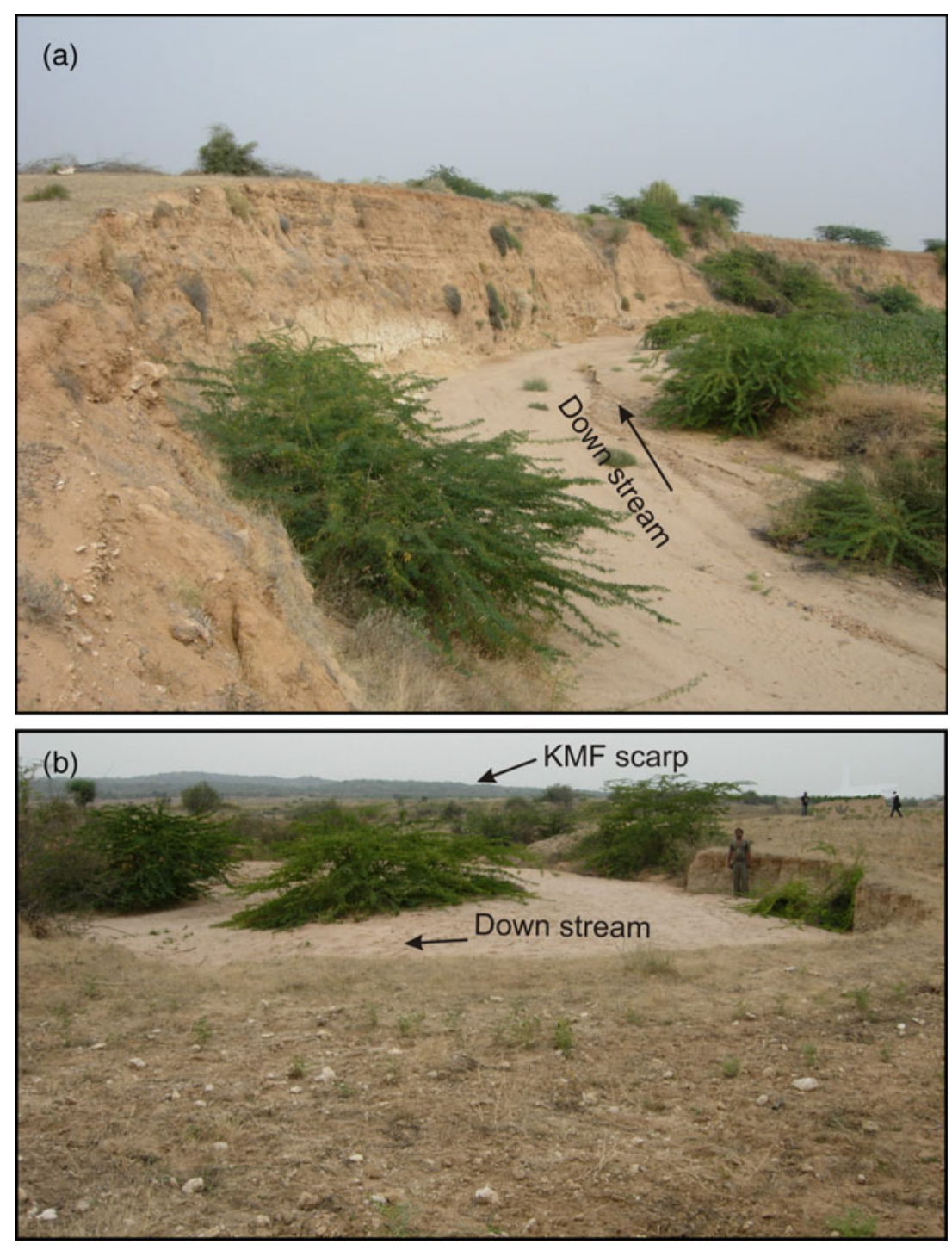

Figure 9. (a) Downstream view of large entrenched meander formed in Quaternary deposits to the north of the KMF scarp in segment-IV. Note the deep incision and overall fine grained nature of the sediment succession exposed in the cliff which is in contrast to the sediments in segments to the west shown in earlier photographs. (b) View of a small incised meander in close to the Banni plain. The KMF scarp is seen in the background. Note the sharp decrease in incision as compared with the incision shown in (a). Rapid decrease in depth of incision in less than two kilometers suggests that neotectonic movements along the KMF are responsible for the incision of Quaternary sediments.

gravel. Overall the coarser gravelly layers show lensoid nature while the sandy horizons are more consistent. Towards north in the upstream direction, a condensed section of $\sim 10 \mathrm{~m}$ is exposed in a small but tight meander. The sediments are similar but are notable for the increased size of the gravel clasts.

Another stream in the east exposes a maximum thickness of $\sim 6 \mathrm{~m}$ Quaternary sediments in an entrenched meander. The sequence overlies the uneven surface of the Mesozoic shale that forms the basal $1 \mathrm{~m}$ of the vertical section (figure 8 , litholog 15 ). The basement rocks are overlain by $2 \mathrm{~m}$ thick horizontally stratified sand followed by $0.5 \mathrm{~m}$ thick fine basal gravel. This is overlain by $3 \mathrm{~m}$ thick massive sand followed by $1 \mathrm{~m}$ thick brown coloured sand. Further east, the exposed alluvial thickness rapidly decreases, while at Khirsara the sediment cover is less than a meter. Overall the Quaternary sediments of this segment are sandy in nature and are in complete contrast to the coarse-grained sediments exposed in other segments to the west. The unconsolidated nature and field relationship suggest that the sediments are younger than the miliolite depositional phase.

In this segment, the sediments are composed of two lithofacies association, sand and sandy gravel. The sand lithofacies exhibit sheet like geometry, good lateral continuity, moderate sorting, massive or weakly horizontally stratified. Massive to 
moderately stratified structure of sand represents the deposits of sheet floods or highly concentrated flows (Rust 1978; Miall 1977; Garzione et al 2003). The thick sandy gravel comprises of well organized pebble clasts and fine-to-coarse grained sandy matrix. It shows cross to horizontal stratification and scoured base which are the indicators of confined channel deposits (Miall 1977). Stratification, moderate sorting and organized gravel clasts in sandy gravel lithofacies indicate transport and deposition by sheet floods in braided stream channels (Rust 1978; Miall 1977; Aziz et al 2003; Kallmeier et al 2010).

\subsection{Segment- $V$}

This segment includes the eastern most part of the KMF zone from Khirsara in the west to Devisar and further east. The general topography of the hill range is relatively lower (figure 2) but remains rugged as evidenced by the deeply incised river courses in the bedrock. The Quaternary sediment cover is the thinnest in this segment. The Quaternary sediments form a thin blanket of structureless and unconsolidated alluvial sands and fine gravels averaging 1-2 $\mathrm{m}$ in thickness covering the Mesozoic and Tertiary rocks. Major Quaternary aggradation phases evident in other segments are absent though the drainages appear to be of similar characteristics. It is surprising that this segment escaped significant Quaternary sedimentation in an identical geological setting where other segments to the west of it show stratigraphically well developed sedimentary sequences. We infer that this particular segment have had much lesser or subdued relief during much of the Quaternary period which did not provide sites for deposition and source area for generation of sediments as well.

\section{Lithostratigraphy}

The Quaternary sediments occur in a thin band $(1-3 \mathrm{~km})$ in front of the north facing range front scarps marking the physiographic expression of the KMF. The scarp is an erosional remnant that owes it origin to faulting along the KMF. The Quaternary sediments form a northward sloping and highly dissected surface that gradually merges with the flat terrain of the Banni plain in the north. The sediments are obviously derived from the hilly terrain of the Northern Hill Range comprising deformed Mesozoic rocks and deposited by various streams in front of the scarps. The Quaternary sediment cover though thin, exhibits wide variation in lithology vertically as well as laterally along the KMF zone. All segments of the KMF zone investigated in the present study, show excellent stratigraphic development, except in the easternmost segment$\mathrm{V}$. The sediments are well exposed along the incised cliffs of north flowing small streams. In general, the maximum exposed thickness is found near to the scarps where the incision is also maximum which rapidly decreases towards north.

The prominent development of the miliolite phase in the study area can be considered as a marker horizon which can be used in correlation with the underlying and overlying phases of the sedimentary record (figure 10). The Quaternary sediments of the KMF zone can be classified into three major aggradation phases (figure 11). The oldest phase includes the sediments occurring below the miliolites. The second is the miliolite phase that includes the aeolian miliolites and valley-fill fluvial miliolites. The youngest phase is the post-miliolite phase that includes all deposits younger than miliolite. The deposits older than the miliolite phase are well exposed in segment-I and II to the north of Jhura and Habo domes, respectively (figure 10). These deposits are dominantly coarse-grained and are composed of clast supported to matrix supported gravels. The striking feature of these deposits is the large size of the clasts that ranges from boulder to pebbles (figure 11). The basal clast supported bouldery gravel seen in the cliff section of the Kaila and Kaswali rivers overlying the uneven surface of the underlying Mesozoic rock form the oldest Quaternary deposits of the KMF zone. This is overlain by several depositional phases of various kinds of gravel deposits. These deposits are unsorted and contain large angular clasts of Mesozoic rocks. The deposits underlying the miliolites imply short transport of the colluvial debris generated in the hilly region presumably due to uplift of the source area in response to neotectonic activity along the KMF. The pre-miliolite sediments can therefore be categorized in general as colluvio-fluvial deposits, which correspond to the premiliolite phase of neotectonic activity along the KMF. These deposits are in sharp contrast to the present day sandy bed load of the various streams and large rivers like the Kaila and Kaswali rivers.

The miliolite phase is the most characteristic Quaternary depositional phase of the region which includes both the aeolian as well as fluvial deposits. These comprise medium-to-coarse grained semicompacted clastic limestones with higher lithic content than the comparable and more intensively studied miliolite rocks in Saurashtra (Biswas 1971). These are described as originally carbonate rich sediments blown by wind from coastal area and deposited as scattered obstacle dunes along the rocky slopes within the hill ranges and in part of the scarps (Biswas 1971). The miliolites are the only dated Quaternary sediments of Kachchh 

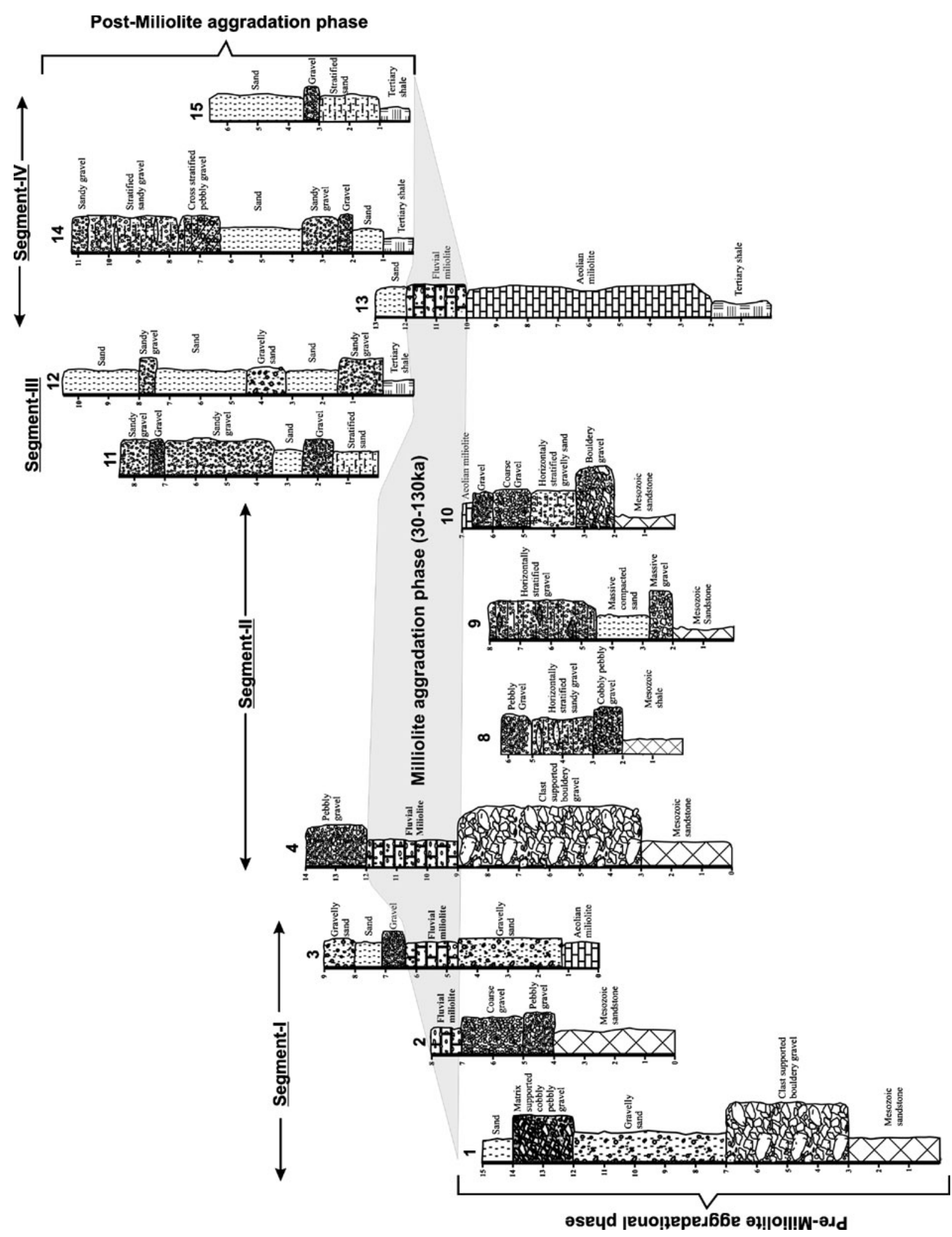


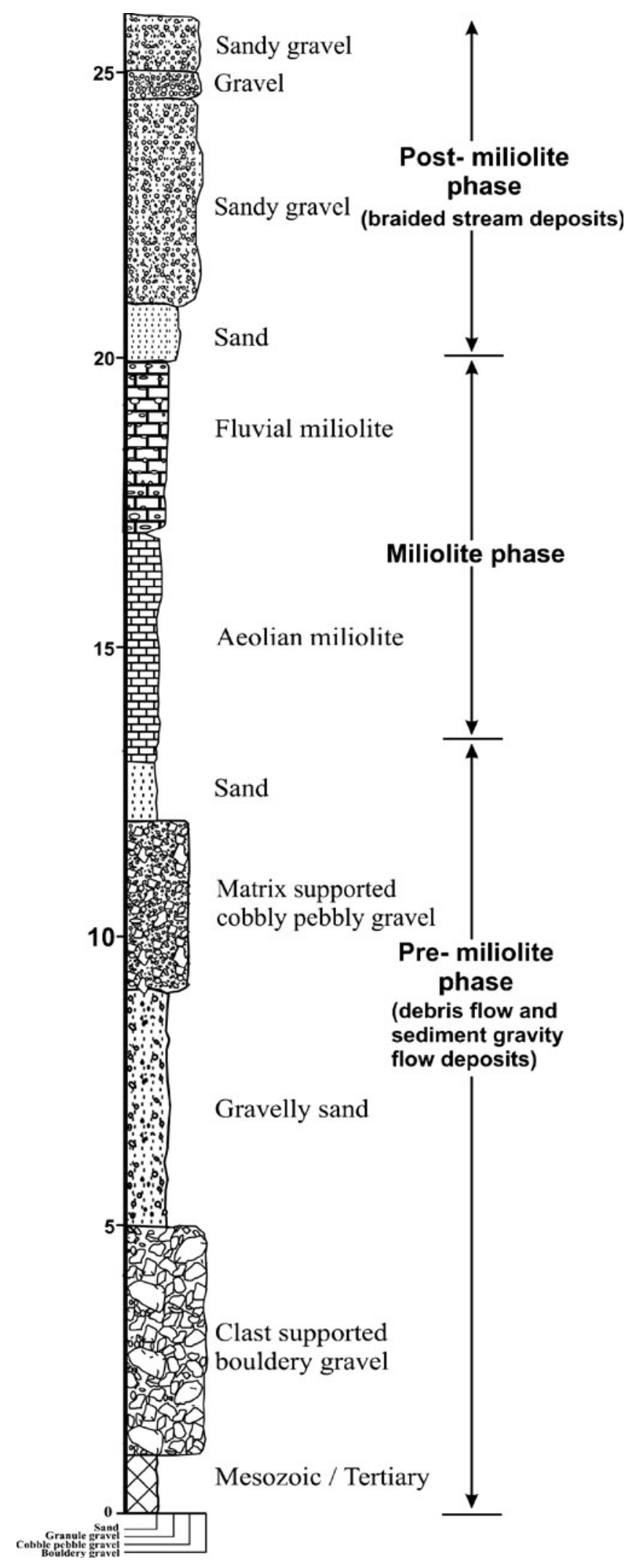

Figure 11. Composite lithostraphy of the Quaternary sediments occurring along the KMF zone in the study area. The vertical scale is in metres. which have regional distribution. Since the lithologic and chronologic correlatability of the miliolites of Kachchh with their more well developed and more intensely investigated counterpart in Saurashtra is already well established and accepted (Baskaran et al 1989; Chakrabarti et al 1993; Somayajulu 1993), they form important reference point for the interpretation of other Quaternary deposits in Kachchh especially in those occurring in the known active fault zones and for which no chronological data are available (e.g., Patidar et al 2007). However, almost all dates are reported from the central Mainland Kachchh and none from the KMF zone. ${ }^{230} \mathrm{TH} /{ }^{234} \mathrm{U}$ ages of the Kachchh miliolite ranges from 30 to 130 ka (Baskaran et al 1989; Chakrabarti et al 1993; Somayajulu 1993). The miliolite phase, therefore, represents an extensive depositional phase all over the Kachchh basin from middle Plistocene to late Plistocene.

Aeolian miliolite comprises fine grained texture while in reworked fluvial miliolite, the presence of varying sizes of clasts of Mesozoic rocks and horizontal stratification is seen. The thickest aeolian miliolite deposit is seen in the Jawaharnagar stream where $\sim 8 \mathrm{~m}$ thick deposit forms dunal morphology and abuts against the KMF scarp where it shows the vertical dip near the scarp. This suggests post-miliolite phase of neotectonic activity along the KMF. Reworking of the aeolian miliolite by fluvial agencies have resulted in the formation of valley-fill miliolite or fluvial miliolite (Biswas 1971; Patidar et al 2007). The maximum exposed thickness of the valley-fill miliolite is seen in the Falay river where the maximum thickness of these deposits is $\sim 3 \mathrm{~m}$.

The post-miliolite phase is represented by the alluvial deposits overlying the miliolites. Typical exposures of the sediments younger than miliolite are found at Wantra and in large incised meanders to the east of Jawaharnagar. These sediments also show lithological heterogeneity along the length of the KMF zone. In segment-I, these consist of cobbly-pebbly gravel with sands where they overlies the miliolite and are tilted. In segmentII, this phase is separated by matrix supported gravel overlying the valley-fill miliolite in Falay river. The clast size here is of pebble size. Further east in segment-III at Wantra, clast size is visibly reduced and the sand content is found to increase. In Wantra section, exposing the postmiliolite deposit, the sediments are unconsolidated and characterized by relatively less amount of gravel deposits. Since the source area is the same, the relatively finer nature of the deposits could be indicative of comparatively less intense neotectonic activity along the KMF in the deposition of post-miliolite sediments. However, the tectonically controlled incision of the Quaternary 
deposits observed in all the segments indicates a post-depositional tectonic activity along the KMF.

\section{Depositional environments and processeses}

The sedimentary characteristics and stratigraphic set-up of the Quaternary sediments of the KMF zone described earlier are suggestive of very specific depositional processes. The geomorphic setting, proximity of the source area and the fact that the deposits overlap an active fault zone are further strong indicators of the nature of sedimentary processes that operated during the deposition of these sediments. The deposits are in sharp contrast to the present day sedimentation that occurs by the seasonally active rivers and the resultant deposits are sandy. Lack of chronologic data and overwhelming imprint of neotectonic activity along the KMF are major contraints for elucidating signatures of the climatic changes.

The oldest aggradation phase comprises of clast and matrix supported gravel of boulder and cobble size and pebbly sand in minor amount which are deposited mainly by debris flow deposits (plastic and pseudoplastic) and sediment gravity flow deposits. Clast shape is angular to subrounded and sorting is very poor and uncommon. Vertical and lateral facies changes are complex and somewhere sharp and have low lateral continuity. The clast supported massive gravel comprises of angular to subangular, massive, disorganized and poorly sorted pebble-cobble-boulder. The bigger boulders are concentrated in the basal part of the unit whereas the top comprises cobbly gravel. They display partially developed grading and total absence of stratification. The facies is laterally extensive and have sharp unconformable contact with the underlying Mesozoic rocks. In some of the sections, coarse-to-medium grained sand lenses are seen. Higher gravel concentration, large clast size, absence of sedimentary structures, little internal sorting are indicative of subaqueous cohesionless, hyperconcentrated pseudoplastic debris flows (Rust 1978; Blair and Mcpherson 1992; Miall 1996; Aziz et al 2003; Garcia et al 2003; Deynoux et al 2005; Dorsey and Roering 2006; Pope et al 2008; Kallmeier et al 2010). The matrix supported gravel lithofacies consists of massive, disorganized pebblecobble with coarse sandy matrix. The gravels are angular to subangular, weakly stratified, poorly sorted and graded. The lithofacies locally exhibits horizontal and cross stratification at some locations. The lithofacies characteristics indicate the deposition by viscous, high strength clast rich debris flows (Rust 1978; Blair and Mcpherson 1992; Miall 1996; Garzione et al 2003; Dorsey and
Roering 2006; Pope et al 2008). The sand lithofacies shows massive nature, show presence of isolated clasts, moderate lateral continuity and poor sorting which suggest the rapid deposition of sand with floating unorganized clasts (Miall 1996). It is interpreted that the structureless fine-to-coarse pebbly sand was deposited as sheet deposits by sediment gravity flows (Miall 1996; Stokes and Mather 2000; Coltorti et al 2010).

Overall, the geometry of the facies is found to be wedge shaped where coarse gravelly deposits show a typical but rapid downslope fining trend. The multi-storyed and superposed character of gravel lithofacies is indicative of episodic deposition presumably by ephemeral streams (Bull 1997; Aziz et al 2003). The facies assemblage observed is typical of alluvial fan sediments (Smith 1986; Mcpherson et al 1987; Wells and Harvey 1987; Blair and Mcpherson 1992; Miall 1996; Bull 1997). Usually, alluvial fan sediments found to occur at tectonically active basin margin (e.g., Mcpherson et al 1987; Leeder et al 1991; Garzione et al 2003; Deynoux et al 2005; Kallmeier et al 2010) and their formation is associated with constant uplift along the active faults.

The younger post-miliolite phase of deposition is represented by comparatively higher sediments comprising sand, gravelly sand and sandy gravel lithofacies deposited largely by stream flows (braided channel) and partially by sheet flood (sediment gravity flows, debris flows). The sandy lithofacies (sand and gravelly sand) show signs of sheet like geometry, good lateral continuity, moderate sorting, massive or weakly stratified. This indicates deposition by sheet floods or highly concentrated flows (Rust 1978; Miall 1977; Garzione et al 2003). The other gravelly (sandy gravel) lithofacies comprises of well organized subrounded-torounded pebble clasts supported by fine-to-coarse grained sandy matrix. It shows horizontal as well as cross stratification and scour and fill structures. The lateral continuity of the deposits is moderate to good. These characteristics indicate the transport and deposition by sheet floods or confined flows in braided-river environment (Rust 1978; Miall 1977; Aziz et al 2003; Kallmeier et al 2010).

Although, the gravel lithofacies deposited by debris flows are common in both the pre- as well as post-miliolite deposits, they are distinguishable as braided-river deposits in the later phase by the presence of cross stratification and pebble sized gravels. Another distinction is that in the alluvial fan deposits the lenses and intergrading of sediment layers is common, in contrast, the braidedriver deposits show comparatively good lateral continuity and grading (Smith 1986; Mcpherson et al 1987). The braid plain deposits juxtaposed over the pre-miliolite colluvio-fluvial sediments deposited as 
alluvial fans indicate reduced level of neotectonic activity during the post-miliolite phase.

\section{Neotectonic implications}

Neotectonics is the prime factor that governs the sedimentation pattern and geomorphic evolution in active fault zones. The Quaternary deposits occurring in the seismically active KMF zone provide important clues for neotectonic evolution. The lateral continuity and excellent stratigraphic development of the deposits in the KMF zone are in a way contrasting with the dominantly rugged rocky landscape of the Kachchh developed over Mesozoic rocks with negligible Quaternary sediment cover. The confinement and deposition of Quaternary sediments in front of the scarps along the KMF zone points to the primary control exerted by neotectonic activity in the generation and deposition of the Quaternary sediments. The rugged hilly terrain of the Northern Hill Range consisting of deformed Mesosoic rocks acted as the source area for the generation of sediments which were transported and deposited in front (north) of the scarps. Tectonic uplift of the hill ranges due to neotectonic activity along the KMF led to the generation of vast amounts of colluvial deposits which were reworked by fluvial agencies and transported northwards. The multi-storeyed sedimentary architecture of the sediments indicates deposition in the form of small coalescing alluvial fans by multidistributary channel systems in the backdrop of an active fault controlled range front. The dominantly coarse grained nature of the pre-miliolite deposits particularly well developed in segments I and II, and the sedimentary characteristics indicate that deposition occurred in phases is mainly by debris flows and sediment gravity flows as discussed in the previous section. Available chronological data suggests that the overlying miliolite deposits represent a prolonged period from middle-to-late Pleistocene (Baskaran et al 1989) thus bracketing the neotectonic activity represented by the colluvio-fluvial deposits to early-to-middle Pleistocene.

Broadly, the overlying aeolian and fluvial miliolites are stratigraphically and lithologically comparable with their more extensively developed and studied counterpart in Saurashtra (Baskaran et al 1989). The aeolian miliolites were deposited as scattered obstacle dunes within the Northern Hill Range and also in the KMF zone in front of the north facing scarps. These were fluvially reworked and deposited over the colluvio-fluvial deposits possibly during the early Holocene. Similar valleyfill miliolites in the Katrol Hill Fault (KHF) zone in central part of the Mainland Kachchh have been related with the humid phase of the early Holocene
(Patidar et al 2007). The nature of neotectonic activity during the deposition of miolilite is not clear as the deposits are scattered and fine grained by virtue of their aeolian origin. Moreover, no fluvial deposits within aeolian miliolites are observed or reported from elsewhere in Kachchh by previous workers. However, vertically disposed aeolian miliolite near the scarps and tilted gravel layers overlying fluvial miliolites indicate post-miliolite tectonic activity along the KMF.

The interlayered sandy gravel and sand deposits overlying the miliolites are striking finer than the pre-miliolite colluvio-fluvial deposits. The finer nature of the deposits, well exposed in segments III and IV, is evidenced by the increased sand content and pebble-sized clasts in the gravel. The sediments were deposited dominantly as sheet floods in shallow braided stream channels. Since the source area for the generation of sediments remained the same, the relatively finer nature of the deposits could be indicative of comparatively less intense neotectonic activity along the KMF in the postmiliolite time. Based on the sedimentary facies and multi-storeyed architecture, we infer braided multidistributary channel systems for the deposition of the post-miliolite Quaternary sediment succession along the KMF zone.

The present day setting of the KMF is in contrast to the one indicated by the exposed Quaternary sediments. Presently the Quaternary deposits form a narrow $1-3 \mathrm{~km}$ wide highly dissected northward sloping surface along the length of the KMF zone. The drainages are deeply entrenched with narrow ephemeral sandy stream channels bound by vertical cliffs exposing the sediments. The depth of incision is maximum near the scarps which rapidly decreases northward as the streams disappear into the Banni plain. This suggests post-depositional tectonic activity along the KMF that resulted in tilting of the Quaternary sediment surface away from the scarps and tectonically controlled fluvial incision and dissection of the sediment sequences.

The variable geomorphic response to neotectonic activity along the KMF is interesting. Many studies exist which describe controls of tectonics and climate on sedimentation and incision but studies that discuss factors that trigger change from deposition to incision under tectonically active conditions are rare. It is difficult to determine the precise causes of change from deposition to incision in the study area even though the KMF continues to be tectonically active as evidenced by the tectonically controlled incision and occurrence of several earthquakes. The role of climate change is ruled out as Kachchh falls in the hyper-arid climatic belt of western India that includes the Thar Desert to the north as well. The scanty rainfall means that the present discharge and stream power 
alone cannot account for the amount of incision observed. Moreover, arid conditions do not favour generation of large amount of sediments in source areas. The sand dominated floor of the present day rivers even within the hill ranges testify to the low degree of sediment generation, stream power and sediment carrying capacity. We therefore believe that marked reduction in sediment supply could be the reason for transformation of rivers from depositional to erosional under uniformly tectonically active conditions. Modelling of changes in sediment flux and incision in tectonically active conditions show that reduction in supply of sediment leads to river incision and/or diversion (Humphrey and Konrad 2000). This also shows that in tectonically active environment, incision is favoured during phases of enhanced tectonic activity (Chen et al 2011). We conclude that, continued neotectonic activity along KMF that continues at the present time is the prime factor responsible for causing incision and dissection of the Quaternary sediments while climate may have played an indirect role in switching off the sediment supply. However, while the role of neotectonic activity is very obvious, the role of climate change needs to be substantiated by further studies.

Our inferences are consistent with previous studies in active fault zones in Kachchh and other parts of the globe which identify variation in rates of tectonic activity as the first order influence on sedimentation and erosion. Tectonically controlled Quaternary deposition reported previously from Kachchh include the vast basin of the ranns, the coastal plain along the Gulf of Kachchh in the south and the Katrol Hill Fault (KHF) zone in the central part of Mainland Kachchh (Biswas 1974; Thakkar et al 1999; Maurya et al 2003b, 2008; Patidar et al 2007, 2008). These sediments were deposited in structurally controlled sites/basins and have provided vital stratigraphic and geomorphic evidences for reconstructing neotectonic evolution of the respective areas (Merh 2005; Maurya et al 2008; Patidar et al 2007, 2008). This indicates the significant role played by neotectonic activity along various active faults including the KMF in controlling the Quaternary sedimentation and geomorphic evolution in the Kachchh basin. However, a comprehensive neotectonic history of Kachchh is yet to emerge as the Quaternary evolutionary history of several other faults presumed to be active is not known.

\section{Conclusions}

The KMF zone is characterized by spatially and vertically heterogeneous assemblage of Quaternary sediments. The confinement and deposition of
Quaternary sediments in front of the KMF scarps points to the primary control exerted by neotectonic activity in the generation and deposition of the Quaternary sediments. The Quaternary sediments of the KMF zone show three major aggradation phases. The oldest phase includes the strikingly coarse grained with large boulders and poorly sorted colluvio-fluvial sediments occurring below the miliolites. The sedimentary characteristics indicate deposition, dominantly by debris flows and sediment gravity flows, as small coalescing alluvial fans in front of the scarps. These deposits suggest pre-miliolite neotectonic activity along the KMF. The second aggradation phase comprises aeolian miliolites and fluvially reworked miliolites that have been previously dated from middle-tolate Pleistocene. The youngest phase is the postmiliolite phase that is represented by comparatively finer sandy gravels, gravelly sands and sand. The sediment characteristics suggest deposition in shallow braided stream channels under reduced level of neotectonic activity. Neotectonic activity along the KMF during post-miliolite time is evidenced by vertical dips of miliolites and tilting of gravels near the scarps. The tectonically controlled incision and dissection of the Quaternary deposits is the result of neotectonic activity that continues at the present day. The overall nature, sedimentary characteristics and geomorphic setting of the sediments suggest that the KMF remained neotectonically active throughout the Quaternary period.

\section{Acknowledgements}

The authors gratefully acknowledge the financial assistance from the Department of Science and Technology (DMM; Project No. SR/S4/ESTG/03/2008) and Ministry of Earth Sciences, Govt. of India (DMM and LSC; Project No. MoES/P.O.(Seismo)/23(638)/2007) for carrying out this study. Constructive reviews by two anonymous reviewers and the Associate Editor helped in improving the quality of the paper.

\section{References}

Aziz H A, Rubio E S, Calvo J P, Hilgen F J and Krijgsman W 2003 Palaeoenvironmental reconstruction of a middle Miocene alluvial fan to cyclic shallow lacustrine depositional system in the Calatayud Basin (NE Spain); Sedimentology 50 211-236.

Baskaran M, Deshpande S V, Rajaguru S N and Somayajulu B L K 1989 Geochronology of miliolite rocks of Kutch, western India; J. Geol. Soc. India 33 588-593.

Bilham R 1998 Slip parameters of the Rann of Kachchh, India, 16 June 1819 earthquake quantified from contemporary accounts; In: Coastal Tectonics (eds) Stewart I S, Vita-Finzi C; Geol. Soc London 146 295-318. 
Biswas S K 1971 The miliolite rocks of Kutch and Kathiawar; Sedim. Geol. 5 147-164.

Biswas S K 1974 Landscape of Kutch - A morphotectonic analysis; Indian J. Earth Sci. 1(2) 177-190.

Biswas S K 1987 Regional tectonic framework, structure and evolution of western marginal basins of India; Tectonophys. 135 307-327.

Biswas S K 1993 Geology of Kutch; K.D. Malaviya Institute of Petroleum Exploration, Dehradun, 2 450p.

Biswas S K and Khattri K N 2002 A geological study of earthquakes in Kachchh, Gujarat, India; J. Geol. Soc. India 60 131-142.

Blair T C and Mcpherson J G 1992 The Trollheim alluvial fan and facies model revisited; Geol. Soc. Am. Bull. 104 $762-769$.

Bull W B 1997 Discontinuous ephemeral streams; Geomorphology 19 227-276.

Chakrabarti A, Somayajulu B L K, Baskaran M and Kumar B 1993 Quaternary miliolites of Kutch and Saurashtra, western India: Depositional environments in the light of physical sedimentary structures, biogenic structures and geochronological setting of the rocks; Senckenbergina Maritima 23 7-28.

Chen Y, Li Y, Zhang Y, Zhang M, Zhang J, Yi C and Liu G 2011 Late Quaternary deposition and incision sequences of the Golmud River and their environmental implications; Quat. Int. 236 48-56.

Chung W Y and Gao G 1995 Source parameters of the Anjar earthquake of July 21, 1956, India and its seismotectonic implications for the Kutch rift basin; Tectonophys. 242 281-292.

Coltorti M, Fazia J D, Rios F P and Tito G 2010 The Nuagapua alluvial fan sequence: Early and Late Holocene human-induced changes in the Bolivian Chaco?; Proc. Geologists' Assoc. 121 218-228.

Deynoux M, Ciner A, Monod O, Karabiyıkoglu M, Manatschal G and Tuzcu S 2005 Facies architecture and depositional evolution of alluvial fan to fan-delta complexes in the tectonically active Miocene Koprucay Basin, Isparta Angle, Turkey; Sedim. Geol. 173 315-343.

Dorsey R J and Roering J J 2006 Quaternary landscape evolution in the San Jacinto fault zone, peninsular ranges of southern California: Transient response to strike-slip fault initiation; Geomorphology 73 16-32.

Garcia A F, Zhu Z, Ku T L, Galdeano C S, Chadwick O A and Chacón Montero J 2003 Tectonically driven landscape development within the eastern Alpujarran Corridor, Betic Cordillera, SE Spain (Almería); Geomorphology 50 83-110.

Garzione C N, DeCelles P G, Hodkinson D G, Ojha T P and Upreti B N 2003 East-west extension and Miocene environmental change in the southern Tibetan plateau: Thakkhola graben, central Nepal; Geol. Soc. Am. Bull. $1153-20$.

Hein F J and Walker R G 1977 Bar evolution and development of stratification in the gravelly braided Kicking Horse River, British Columbia; Canadian J. Earth Sci. $14562-570$.

Humphrey N F and Konrad S K 2000 River incision or diversion in reponse to bedrock uplift; Geology 28 43-46.

Kallmeier E, Breitkreuz C, Kiersnowski H and Geißler M 2010 Issues associated with the distinction between climatic and tectonic controls on Permian alluvial fan deposits from the Kotzen and Barnim Basins (North German Basin); Sedim. Geol. 223 15-34.

Leeder M R, Seger M J and Stark C P 1991 Sedimentation and tectonic geomorphology adjacent to major active and inactive normal faults, southern Greece; J. Geol. Soc. London 148 331-343.

Mcpherson J G, Shanmugam G and Moiola R J 1987 Fandeltas and braid deltas: Varieties of coarse-grained deltas; Geol. Soc. Am. Bull. 99 331-340.

Maurya D M, Thakkar M G and Chamyal L S 2003a Implications of transverse fault system on tectonic evolution of Mainland Kachchh, western India; Curr. Sci. 85 661-667.

Maurya D M, Bhandari S, Thakkar M G and Chamyal L S 2003b Late Quaternary fluvial sequences of southern Mainland Kachchh, western India; Curr. Sci. 84 1056-1064.

Maurya D M, Thakkar M G, Patidar A K, Bhandari S, Goyal B and Chamyal L S 2008 Late Quaternary geomorphic evolution of the coastal zone of Kachchh, western India; J. Coastal Res. 24 746-758.

Miall A D 1977 A review of the braided-river depositional environment; Earth Sci. Rev. 13 1-62.

Miall A D 1996 The geology of fluvial deposits; Springer, Berlin, 582p.

Merh S S 2005 The Great Rann of Kachchh: Perception of a field geologist; J. Geol. Soc. India 65 9-25.

Patidar A K, Maurya D M, Thakkar M G and Chamyal L S 2007 Fluvial geomorphology and neotectonic activity based on field and GPR data, Katrol hill range, Kachchh, western India; Quat. Int. 159 74-92.

Patidar A K, Maurya D M, Thakkar M G and Chamyal L S 2008 Evidence of neotectonic reactivation of the Katrol Hill Fault during late Quaternary and its GPR characterization; Curr. Sci. 94 338-346.

Pope R, Wilkinson K, Skourtsos E, Triantaphyllou M and Ferrier G 2008 Clarifying stages of alluvial fan evolution along the Sfakian piedmont, southern Crete: New evidence from analysis of post-incisive soils and OSL dating; Geomorphology 94 206-225.

Rust B R 1978 Depositional models for braided alluvium, In: Fluvial Sedimentology (ed.) Miall A D, Can. Soc. Petrol. Geol. Mem. 5 605-625.

Smith G A 1986 Coarse-grained nonmarine volcaniclastic sediment and depositional processes; Geol. Soc. Am. Bull. 97 1-10.

Somayajulu B L K 1993 Age and mineralogy of the miliolites of Saurashtra and Kachchh, Gujarat; Curr. Sci. 64 926-928.

Stokes M and Mather A E 2000 Response of PlioPleistocene alluvial systems to tectonically induced baselevel changes, Vera Basin, SE Spain; J. Geol. Soc. London $157303-316$.

Thakkar M G, Maurya D M, Rachna R and Chamyal L S 1999 Quaternary tectonic history and terrain evolution of the area around Bhuj, Mainland Kachchh, western India; J. Geol. Soc. India 53 601-610.

Wells S G and Harvey A M 1987 Sedimentologic and geomorphic variations in storm-generated alluvial fans Howgill Fells, northwest England; Geol. Soc. Am. Bull. 98 182-198. 